\title{
Adoption of Al-empowered industrial robots in auto component manufacturing companies
}

Article

Accepted Version

Pillai, R., Sivathanu, B., Mariani, M., Rana, N. P., Yang, B. and Dwivedi, Y. (2022) Adoption of Al-empowered industrial robots in auto component manufacturing companies. Production Planning and Control, 33 (16). pp. 1517-1533. ISSN 09537287 doi: https://doi.org/10.1080/09537287.2021.1882689 Available at https://centaur.reading.ac.uk/93387/

It is advisable to refer to the publisher's version if you intend to cite from the work. See Guidance on citing.

To link to this article DOI: http://dx.doi.org/10.1080/09537287.2021.1882689

Publisher: Taylor \& Francis

All outputs in CentAUR are protected by Intellectual Property Rights law, including copyright law. Copyright and IPR is retained by the creators or other copyright holders. Terms and conditions for use of this material are defined in the End User Agreement.

www.reading.ac.uk/centaur 
Central Archive at the University of Reading

Reading's research outputs online 
Adoption of AI-empowered Industrial Robots in Auto Component Manufacturing Companies

Rajasshrie Pillai $^{\mathrm{a}}$, Brijesh Sivathanu ${ }^{\mathrm{b}}$, Marcello Marianic ${ }^{\mathrm{c}}$, Nripendra P. Rana ${ }^{\mathrm{d}}$, Bai Yang $^{\mathrm{e}}$, Yogesh K. Dwivedi ${ }^{\mathrm{f}}$

aDepartment of Management, Pune Institute of Business Management, Pune, India

${ }^{\mathrm{b}}$ Department of Management, Sri Balaji University, Pune, India

${ }^{c}$ Henley Business School, University of Reading, UK

${ }^{\mathrm{d}}$ School of Management, University of Bradford, UK

${ }^{\text {e}}$ School of Management, Chongqing Technology and Business University, China

${ }^{\mathrm{f}} \mathrm{Sch}$ ool of Management, Swansea University, UK 


\title{
Adoption of AI-empowered Industrial Robots in Auto Component Manufacturing Companies
}

\begin{abstract}
The usage of AI-empowered Industrial Robots (InRos) is booming in the Auto Component Manufacturing Companies (ACMCs) across the globe. Based on a model leveraging the Technology, Organisation, and Environment (TOE) framework, this work examines the adoption of InRos in ACMCs in the context of an emerging economy. This research scrutinizes the adoption intention and potential use of InRos in ACMCs through a survey of 460 senior managers and owners of ACMCs in India. The findings indicate that perceived compatibility, external pressure, perceived benefits and support from vendors are critical predictors of InRos adoption intention. Interestingly, the study also reveals that IT infrastructure and government support do not influence InRos adoption intention. Furthermore, the analysis suggests that perceived cost issues negatively moderate the relationship between the adoption intention and potential use of InRos in ACMCs. This study offers a theoretical contribution as it deploys the traditional TOE framework and discovers counter-intuitively that IT resources are not a major driver of technology adoption: as such, it suggests that a more comprehensive framework than the traditional RBV should be adopted. The work provides managerial recommendations for managers, shedding light on the antecedents of adoption intention and potential use of InRos at ACMCs in a country where the adoption of InRos is in a nascent stage.
\end{abstract}

Keywords: Industrial Robots, Auto Component Manufacturing, Adoption, Potential Use, TOE

\section{Introduction}

AI-empowered Industrial Robots (InRos) have significantly changed the face of the manufacturing industry across the globe. AI-empowered Industrial Robots are a particular set of automated handling devices, defined by ISO (Standard 8373:1994) as "an automatically controlled, re-programmable, multipurpose manipulator programmable in three or more axes" (Armbruster et al. 2005 p.7). In today's era, AI-empowered InRos are driven by advanced technologies such as machine learning, Internet of Things, Artificial intelligence and deep learning (Pan 2016), which are helping to improve decision making and increase the production and productivity (Bibby and Dehe 2018; Dhawan et al. 2018; Duan et al. 2019; Dwivedi et al. 2019; Grover, Kar and Dwivedi 2020; Mariani and Borghi 2019; Tapiero 1990). InRos are utilised in industrial painting, welding, ironing, testing, pick and place, product inspection and assembly (Armbruster et al. 2005) applications. 
Artificial intelligence (AI) technology is applied in the manufacturing industry to make InRos perform intelligent work ( $\mathrm{Li}$ et al. 2017). In this work, we define AI as non-human intelligence programmed to perform particular activity or tasks (Dwivedi et al. 2019; Huang and Rust 2018). The common meaning and purpose of AI is "the increasing capability of machines to perform specific roles and tasks currently performed by humans within the workplace and society in general" (Dwivedi et al. 2019: p.2). Prior to the advent of AI technology, InRos were designed as mechanical devices that are multifunctional and performed a number of preprogrammed tasks in an organisation (Brady et al. 2012). AI is enabling InRos to automate the process in an enhanced way, as robots are increasingly able to acquire knowledge, learn, solve problems in almost real time and perform tasks with an enhanced level of accuracy (Dwivedi et al. 2019; Kaplan and Haenlein 2019; Pillai et al. 2020; Russell et al. 2016). This study focuses exactly on intelligent InRos that not only are automated, but can deal with tasks that also entail planning, controlling, communicating and optimizing the production (Kopacek 1999; Li et al. 2017; Mani 2018; Paryanto et al. 2015). Acccordingly, the object of our study is an advanced form of InRos that are AI-empowered. There will be 2.1 million number of AIempwoered InRos installed across the world, with projections of an increase of $16 \%$ in Asia by 2021 (IFR 2018). The AI-powered InRos are enabling automation of press shops, weld shops, paint shops and cast shops which is lowering the cost of manufacturing in automobile companies (PWC 2019). InRos are extensively employed in the automotive industry (Cheng et al. 2019; IFR 2018). Cheng et al. (2019) argue that market conditions and governments are playing a crucial role in the adoption of robots across the industry in China. Worldwide, India has the largest manufacturing base of automobiles and auto components whose turnover is predicted to grow from USD 51.4 to 282.8 billion by 2026 (PWC 2019). The usage of AIempowered Industrial Robots in ACMCs is increasing as it is helping companies to speed up the manufacturing process, improve productivity and make research of development activities 
more effective (Dhawan et al. 2018; PWC 2019). ACMCs are manufacturers of engine parts, chassis and body, electrical parts, suspension and braking parts, steering and drive transmission parts along with equipment for automobile companies (IBEF 2019). InRos help improve the flexibility in production and increase the return on investment. AI-empowered Industrial Robots' adoption is necessary for companies to be competitive in the marketplace. From a theoretical and empirical perspective, most of the research on advanced industrial manufacturing technologies (including InRos) is focused on the developed countries in the West rather than emerging economies such as India. However, different environmental settings and cultural contexts might affect differently the drivers and outcomes of InRos adoption. Contextual and institutional differences between developed and emerging economies such as India provided the authors with a crucial motivation to conduct this research. Hence, focusing on the Indian context is important to investigate the factors leading to the adoption of InRos from the perspective of firms (Mathews 2017; PWC 2018) that have to operate in emerging economies.

There are new recent technologies adoption studies from the Indian perspective with respect to cutting hedge digital technologies such as blockchain as well as smart manufacturing (Kamble et al. 2019; Mittal et al. 2019; Queiroz and Fosso Wamba 2019; Schuetz and Venkatesh 2019). However, there is a dearth of studies discussing the adoption of InRos from the firms' perspective in the Indian context (Mani 2018). Currently, the adoption of robots has been examined in different industries including the construction industry (Davila Delgado et al. 2019), home healthcare (Alaiad and Zhou 2014), hospitality, travel and tourism industries (Ivanov et al. 2018; Ivanov et al. 2019; Tung and Au 2018), manufacturing (Armbruster et al. 2005), FinTech (Belanche, Casaló, and Flavián 2019), other service industries (Borghi \& Mariani 2020; Gursoy et al. 2019) and education and teaching (Park and Kwon 2016). Extant research discusses the impact of InRos on workers (Dauth et al. 2017). Turja and Oksanen 
(2019) analysed various individual-level factors related to robot acceptance at work. Experimental research has been carried out to study the acceptance and attitude (Müllerabdelrazeq et al. 2019) and key concerns and expectations (Kildal et al. 2018) towards collaborative industrial robots. The Technology Acceptance Model (TAM) was deployed to apprehend the acceptance of collaborative industrial robots in production systems (Bröhl et al. 2016). These studies mainly discuss the workers' and users' perspectives on InRos adoption. Simoes et al. (2019) conducted a qualitative research in manufacturing companies to explore the drivers affecting collaborative robots adoption and found that ergonomics, operational efficiency, industrial innovation and human factors are the key drivers. So far, no studies have developed an adoption model of InRos by leveraging an organisational perspective. However, there is an increasing necessity to examine the factors affecting the adoption of InRos within an organisation's perspective (Turja and Oksanen 2019; Müller-abdelrazeq et al. 2019) as it is a rising concern for ACMCs to adopt InRos to survive the growing threats and stay competitive in the market. In India, the adoption of technologies such as AI in general and AI-empowered InRos, are still in the nascent stage (ACMA 2019). Mani (2018) found that though the usage of InRos is increasing in India, the country is still lagging behind compared to other Asian countries like Japan. There are barely a few multinational ACMCs who could afford the use of AI empowered InRos for manufacturing. Hence, this study aims to examine the adoption intention and potential usage of AI-empowered InRos in ACMCs. Therefore, this work's overarching research question is framed as follows:

$R Q$ : What are the factors affecting the adoption and potential use of InRos in ACMCs?

To be clear, the aim of this work is not merely testing adoption intention of InRos, but rather to understand more subtly the drivers of adoption intention. This is consistent with the large body of literature that has tested the drivers of adoption of technologies (such as Big Data or RFID) once those technologies were already widely used and adopted in practice (Fosso 
Wamba et al. 2016; Hossain et al. 2017; Sun et al. 2018) Accordingly, our work can be read as a both exploratory and explanatory study trying to disentangle the drivers of adoption and attempting to examine in a subtle way which of those drivers actually play a role in the adoption of InRos.

To uncover the adoption factors of InRos from an organisational perspective, the Technology, Organisation, and Environment (TOE) framework is chosen in this work. TOE has been mostly deployed in the information systems literature and broadly explains the implementation and adoption of innovation (Depietro et al. 1990; Dauth et al. 2017; Hassan et al. 2015; Jia et al. 2016; Kumar et al. 2016; Ramanathan et al. 2017; Sun et al. 2018; Wei et al. 2015; Yeh and Chen 2018). Therefore, TOE is appropriate to understand the adoption of innovative solutions embedding a user interface combined with hardware and software, such as InRos. The InRos adoption in ACMCs is a complex process and an organisational perspective needs to be taken (Müller-abdelrazeq et al. 2019; Turja and Oksanen 2019) his study is unique and helpful for senior management in ACMCs to understand the factors of adoption as InRos require a huge amount of investment in terms of time, money and efforts. This study is also beneficial to marketers and manufacturers of InRos for ACMCs. Accordingly, this research provides insights for scholars in production and planning by developing a conceptual model for InRos adoption. Furthermore, the proposed model is empirically validated. The outcome of this work will provide directions for ACMCs to develop suitable strategies for InRos adoption.

The remaining part of the paper is structured as follows: Section 2 reviews the relevant theory, including the TOE framework that is used to develop the key research hypotheses. Section 3 illustrates the research design and methodology, and the methods used to test the proposed model. In the fourth section, the work elucidates the results and discusses them. The fifth section describes managerial and theoretical implications. Finally, the last and concluding section discusses the limitations of the study and proposes a research agenda. 


\section{Theoretical Background}

\section{The Technology, Organisation and Environment (TOE) framework}

In the Nineties Depietro et al. (1990) designed and proposed the TOE framework. The framework is a firm-level theory that discusses the adoption of innovative technologies by using three perspectives: technology, organisation and environment. The technological perspective highlights the distinctive features and characteristics of the technology; the organisational perspective emphasises the organisational adoption-related attributes; the environmental perspective revolves around the factors related to the surroundings (Baker 2011; Henderson et al. 2012). That said, this theoretical framework does not provide a particular set of factors for the analysed problem; rather it categorises the factors into the individual constructs where the technology adoption occurs (Wang, et al. 2010). The TOE framework has been also deployed to explore the adoption of augmented reality (Masood and Egger 2019), AI adoption in talent acquisition (Pillai and Sivathanu 2020), intelligent robots in manufacturing SMEs (Choi et al. 2018), software as a service (SaaS) (Oliveira et al. 2019), Industrial Internet of Things (Sivathanu 2019) and Industry 4.0 in the automotive industry in China (Lin et al. 2018). This paper intends to study the adoption of robots in manufacturing companies regardless of their size. A summary of the research stream related to the use of the TOE framework to explain the adoption of innovative advanced technologies such as SaaS, Industry 4.0, Industrial IoT, Business Intelligence System, 3D printing, RFID and e-procurement is shown in Table 1.

Table 1. TOE literature for Advanced Technology Adoption

\begin{tabular}{|l|l|l|}
\hline Technology & Reference & Variables Examined \\
\hline $\begin{array}{l}\text { e-supply chain } \\
\text { management }\end{array}$ & Lin (2014) & $\begin{array}{l}\text { Perceived benefits*, perceived cost*, firm size, top management } \\
\text { support*, absorptive capacity*, trading partner influence, } \\
\text { competitive pressure* }\end{array}$ \\
\hline
\end{tabular}




\begin{tabular}{|c|c|c|}
\hline Cloud computing & $\begin{array}{l}\text { Oliveira et al. } \\
(2014)\end{array}$ & $\begin{array}{l}\text { Security concerns, cost saving*, relative advantage*, } \\
\text { complexity*, compatibility*, technology readiness*, top } \\
\text { management support*, firm size*, competitive pressure, } \\
\text { regulatory support }\end{array}$ \\
\hline RIFD & Wei et al. (2015) & $\begin{array}{l}\text { Relative advantage, complexity, it infrastructure*, managerial } \\
\text { capability*, absorptive capacity*, competition intensity, } \\
\text { regulatory support, environmental uncertainty* }\end{array}$ \\
\hline RFID & $\begin{array}{l}\text { Wamba et al. } \\
(2016)\end{array}$ & $\begin{array}{l}\text { Relative advantage*, complexity, compatibility*, firm size, } \\
\text { competitive pressure, firm's geographic location, industry } \\
\text { sector, country of ownership*, manager's age, manager's } \\
\text { gender, manager's education, (control variable: industry, sector, } \\
\text { country) }\end{array}$ \\
\hline $\begin{array}{l}\text { Internet } \\
\text { marketing }\end{array}$ & Shaltoni (2016) & $\begin{array}{l}\text { Relative advantage*, } \quad \text { complexity, } \quad \text { compatibility*, } \\
\text { innovativeness*, competitor pressure*, customer pressure* }\end{array}$ \\
\hline ERP & $\begin{array}{l}\text { Awa and Ojiabo } \\
(2016)\end{array}$ & $\begin{array}{l}\text { ICT infrastructure*, technical know-how*, perceived } \\
\text { compatibility*, perceived values*, security*, size of the firm*, } \\
\text { demographic composition*, scope of business operation*, } \\
\text { subjective norms*, competitive pressure*, external support*, } \\
\text { trading partner readiness* }\end{array}$ \\
\hline ERP solution & Awa et al. (2016) & $\begin{array}{l}\text { ICT infrastructure*, technical know-how*, perceived } \\
\text { compatibility*, perceived values*, security*, scope of business } \\
\text { operation*, demographic composition*, size of firm*, subjective } \\
\text { norms*, external support*, competitive pressure*, trading } \\
\text { partner readiness* }\end{array}$ \\
\hline E-procurement & $\begin{array}{l}\text { Hassan et al. } \\
\text { (2017) }\end{array}$ & $\begin{array}{l}\text { Relative advantage*, compatibility*, complexity, top } \\
\text { management support, employee knowledge, external pressure* }\end{array}$ \\
\hline RFID & $\begin{array}{l}\text { Hossain et al. } \\
\text { (2017) }\end{array}$ & $\begin{array}{l}\text { Interoperability of components*, industry wide technology } \\
\text { readiness*, organizational readiness*, market scope*, } \\
\text { competitive market pressure*, data inconsistency* }\end{array}$ \\
\hline $\begin{array}{l}\text { Augmented } \\
\text { reality }\end{array}$ & $\begin{array}{l}\text { Masood and } \\
\text { Egger (2019) }\end{array}$ & $\begin{array}{l}\text { System configuration*, technology hardware readiness*, } \\
\text { technology compatibility*, external support*, organization fit*, } \\
\text { use barrier, }\end{array}$ \\
\hline Industry 4.0 & Lin et al. (2018) & $\begin{array}{l}\text { IT Maturity*, technology incentives*, perceived benefits*, } \\
\text { external pressure*, government policies* }\end{array}$ \\
\hline $\begin{array}{l}\text { Business } \\
\text { intelligence } \\
\text { system }\end{array}$ & $\begin{array}{l}\text { Puklavec et al. } \\
\text { (2018) }\end{array}$ & $\begin{array}{l}\text { Relative advantages, cost*, bis part of erp*, rational decision } \\
\text { making culture*, management support*, project champion*, } \\
\text { organizational data environment*, organizational readiness*, } \\
\text { external support, size and industry }\end{array}$ \\
\hline Intelligent robot & Choi et al. (2018) & $\begin{array}{l}\text { Direct usefulness*, indirect usefulness*, organizational } \\
\text { support*, industry pressure*, governmental pressure* }\end{array}$ \\
\hline $\begin{array}{l}\text { 3D printing } \\
\text { (Factors Studied) }\end{array}$ & $\begin{array}{l}\text { Yeh and Chen } \\
\text { (2018) }\end{array}$ & $\begin{array}{l}\text { Technology infrastructure, technology integration, relative } \\
\text { advantage, organizational readiness, top management support, } \\
\text { managerial obstacles, competitive pressure, expectations of } \\
\text { market trends, trading partner, government policy, machine cost, } \\
\text { labour cost, material cost }\end{array}$ \\
\hline Industrial IoT & Sivathanu (2019) & $\begin{array}{l}\text { IIoT infrastructure*, IIoT expertise*, relative advantage*, } \\
\text { compatibility*, cost*, security and privacy*, top management } \\
\text { support*, organizational readiness*, competitive pressure*, } \\
\text { support from technology vendor* }\end{array}$ \\
\hline SaaS & $\begin{array}{l}\text { Oliveira et al. } \\
(2019)\end{array}$ & $\begin{array}{l}\text { Technology competence*, top management support*, coercive } \\
\text { pressure*, normative pressure*, mimetic pressure*, (control } \\
\text { variables) industry sector, firm size }\end{array}$ \\
\hline
\end{tabular}

\section{Research Model and Hypotheses}

The model proposed and tested in this research is based on the TOE framework and is 
2) organisational and 3) environmental. In the technological dimension, perceived compatibility (Awa and Ojiabo 2016; Masood and Egger 2019; Wamba et al. 2016) and perceived benefits (Lin 2014; Lin et al. 2018; Oliveira and Martins 2010) are considered. IT infrastructure (Wei et al. 2015) is considered as a major driver within the organisational perspective. Leveraging on previous studies within the environmental perspective, we consider external pressure (Aboelmaged 2014; Hassan et al. 2017; Guo et al. 2017; Lin 2014) support from vendors (Alshamaila et al. 2013; Ghobakhloo et al. 2011) and government support (Hwang et al. 2016; Lin et al. 2018; Osakwe et al. 2016) as key drivers and antecedents of InRos adoption.

This study intended to explore further the potential use of InRos as influenced by the adoption intention (Schmidt et al. 2015). As InRos require huge financial investment, this study explores the moderating effect of perceived cost issues between adoption intention and potential use of InRos, as cost is considered as a barrier for adoption (Maduku et al. 2016; Reyes et al. 2016).

\section{Figure 1. Proposed Theoretical model}




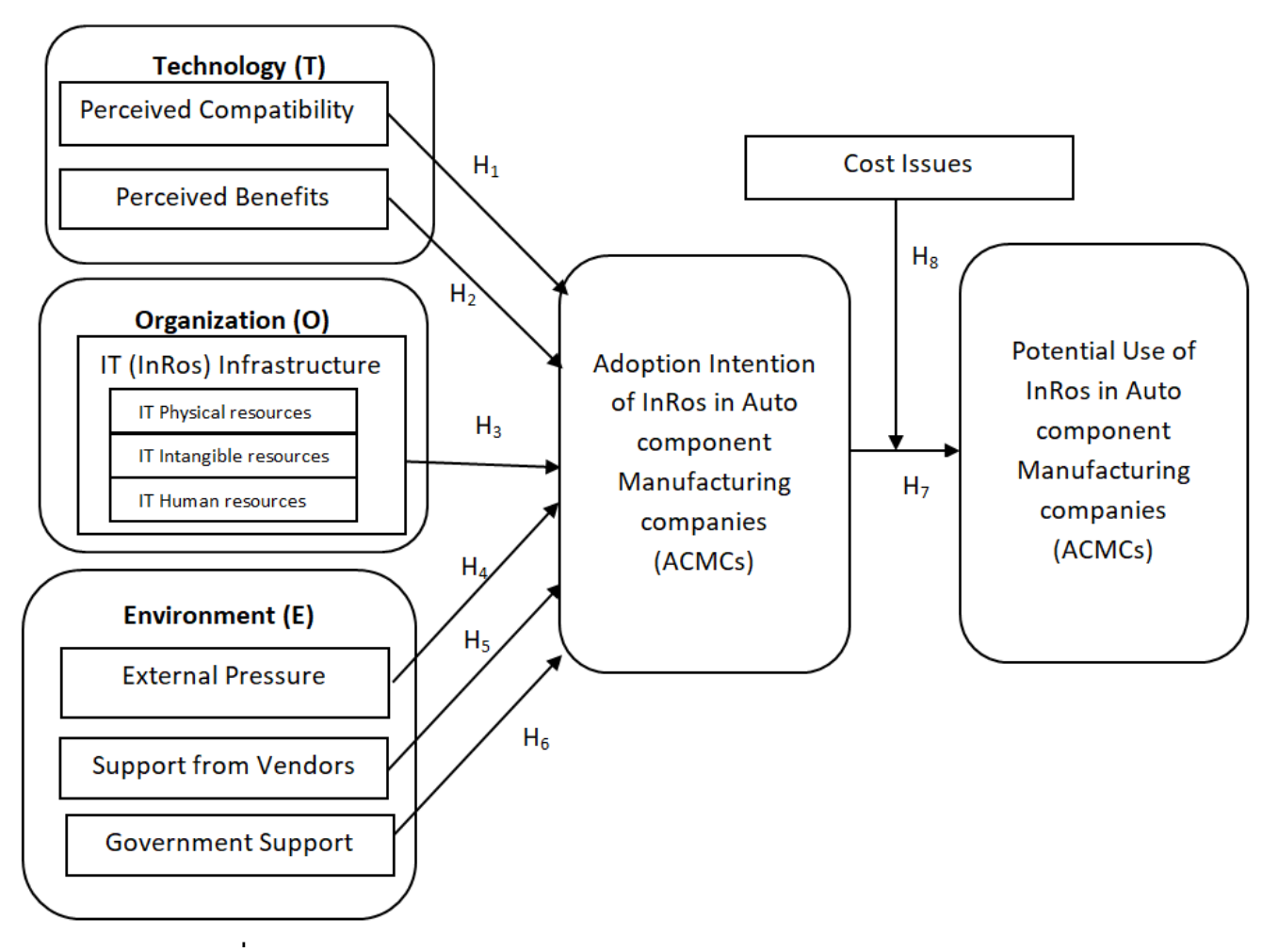

Source : Depietro et al. (1990)

\section{Technology $(T)$}

\section{Perceived Compatibility}

Perceived compatibility is our first antecedent and relates to "the degree to which an innovation is consistent with the existing business processes, practices and value systems" (Roger 1995: p.223). An innovation that is perceived as consistent with the existing business processes, practices and value system, is considered as compatible with the organisation (Roger 1995). Compatibility helps to lower the menace of possible innovation adopters and makes it easier for the organisation to achieve its goals and purposes (Grover 1993). In previous studies, perceived compatibility has been found to be a predictor of the adoption of innovative technologies such as ERP (Awa and Ojiabo 2016), RFID (Wamba et al. 2016), e-procurement (Hassan et al. 2017). Masood and Egger (2019) found that compatibility of technology affects the implementation of augmented reality (AR) in a number of industries including aerospace, automotive, chemical/pharmaceutical, commerce, construction, energy, electronics, FMCG, 
mining and transport. Research conducted on service enterprises in Nigeria found that compatibility negatively influences the adoption of technology (Awa et al. 2017). InRos are multi-purpose in function and are utilised for various production processes such as assembling, painting, welding, packaging, testing and inspection of production (Graetz and Michaels 2018). InRos require unique and customised programming as retrofitting is a challenge with AIempowered Industrial Robots in ACMCs. The integration and fitting of InRos with current equipment in the manufacturing firms is a challenge (Teulieres et al. 2019). Hence, the above discussion leads to formulating the below hypothesis:

$H_{1}$ : Perceived compatibility positively influences the adoption of InRos in ACMCs.

\section{Perceived Benefits}

Perceived benefits comprise both direct and indirect benefits. Direct benefits consist of "operational savings related to the internal efficiency of the organisation" (Iacovou et al. 1995: p.468). Indirect benefits instead relate to "the impact of technology on the business processes and relationships" (Iacovou et al. 1995: p.468). Perceived benefits pertain to the expected advantages that the adoption of innovative technology can offer to the organisation (Oliveira and Martins 2010). Managers' awareness of the benefits of the innovation might lead to an increase of the resources (i.e., financial, technological and managerial) required to adopt the focal innovation (Iacovou et al. 1995). Potential adopters evaluate the outcome of their adoption behaviour based on the perceived usefulness resulting from the new technology (Lin 2014; Venkatesh and Davis 2000). A study of strategic reactions to Industry 4.0 technologies of automotive manufacturing organisations in China found that perceived benefits increase the usage of advanced technology in manufacturing as they help improve smart manufacturing and supply chain performance (Lin et al. 2018). The study of innovative technology adoption confirms the positive effect of perceived benefits on the adoption of e-business (Oliveira and Martins 2010) and e-supply chain management (Lin 2014). Adopting InRos generates various 
benefits such as performing dangerous tasks in hostile conditions, improve product quality and increase productivity (Soffar 2019). Hence, the following relationship needs to be examined: $\mathrm{H}_{2}$ : Perceived Benefits positively influence the adoption of InRos in ACMCs.

\section{Organisation $(O)$}

\section{IT Infrastructure}

IT infrastructure is a shared information delivery base, whose business functionality has been defined in terms of its reach and range (Keen 1991). In this research, in line with Grant (1991), IT infrastructure consists of three components: a) IT Tangible Resources that are made up by the IT components which are physical in nature; b) IT Intangible Resources that consist of customer orientation, synergy and knowledge assets; c) IT Human Resources that include IT skills, which are managerial and technical. The Resource Based View theory (Barney 1991, 2001) - while not being a major conceptual cornerstone of this work - discusses the importance of resources (Barney 1991, 2001; Bharadwaj 2011) a part of which for InRos are represented by IT infrastructure. Based on the RBV theory (Bharadwaj 2011), highly developed and integrated IT infrastructure enables the adoption of innovative IT applications in an organisation. Hence, tangible resources might affect InRos adoption. Human resources include managerial skills and IT technology-related skills as both these skillsets are required to trigger acceptance of InRos within the ACMCs context. As the adoption of InRos would require processes re-design and more co-ordination between the managers, HR is considered an important factor for InRos adoption. Technical skills are required for the design, analysis and implementation of new processes in business (Bharadwaj 2011). Customer orientation is an important element for innovation adoption. Customer-oriented organisations would look for innovations that would contribute to customer satisfaction (Wei et al. 2015). ACMCs would adopt InRos as they might help to speed up the production of auto components based on customers' needs and requirements. Hence, customer orientation is taken into account as a 
driver of InRos adoption in ACMCs. Knowledge assets are necessary to adopt InRos in ACMCs as employees should have strong skillsets and knowledge about the innovation associated with InRos. Synergy relates to resource sharing capabilities between the various divisions in an organisation (Bharadwaj 2011; Teece et al. 2007). Organisations that share information and knowledge among their various divisions are quick and agile in understanding customers' and markets' needs. InRos would require quick communication and enable companies to share the information between planning, purchase, production and warehousing divisions. Therefore, intangible resources such as synergy might positively affect InRos adoption. Wei et al. (2015) found that IT infrastructure influences the assimilation of RFID. Bharadwaj (2011) discusses that IT infrastructure provides the competitive advantage and is a major resource in any organisation. Hence, we formulate the following hypothesis in the context of InRos:

$H_{3}$ : IT Infrastructure positively influences the adoption of InRos in ACMCs.

\section{Environment (E)}

\section{External Pressure}

In today's technology-driven manufacturing environment, ACMCs are facing pressure from competitors and customers for precise and faster production of auto-components by using InRos (Reyes et al. 2016; Lin et al. 2018) which, is considered as external pressure in this research. External pressure is an important antecedent of the adoption of innovative technology (Aboelmaged, 2014; Guo et al. 2017; Hassan et al. 2017; Lin, 2014). Manufacturing firms are facing pressure to accept advanced technology to be competitive (Huang et al. 2008) in the Indian market (Sangani 2019). Global automobile companies are coming up with new models of vehicles to face the competition. ACMCs have to provide new and customized products faster based on customers' requirements and InRos might help Indian ACMCs to fulfill the 
automotive companies' needs (OEMupdate, 2018). Hence, the following hypothesis is formulated:

H4: The external pressure positively influences the adoption of InRos in ACMCs.

Support from vendors

Marketing activities of innovative technology along with the training and support provided by new technology vendors is defined as Technology vendor support (Maduku et al. 2016). The marketing strategies of technology vendors influence new technology adoption decisions (Alshamaila et al. 2013). The employees and the management are generally unaware of new technologies; hence, they need training from technology vendors and support from the vendors would affect the decision of adoption of the technology (Al-Qirim, 2007; Ghobakhloo et al. 2011). The present innovative technology literature confirms the influence of technology vendor support on adoption (Alshamaila et al. 2013; Ghobakhloo et al. 2011). In a mobile marketing adoption study, scholars found that if the employees have the capability to understand the technology, then the technology vendor support would not be a significant predictor of new technology adoption (Maduku et al. 2016). InRos is a new, highly sophisticated technology for ACMCs in India and would require vendor support. Therefore we formulate the following hypothesis:

H5: Support from InRos' vendors positively influence the adoption of InRos in ACMCs.

\section{Government support}

It is the willingness of the government to promote and support new technology and provide suitable standards and policies to encourage adoption (Lin and Ho 2009; Zhu and Kraemer 2005). Government support encompasses initiatives taken by the government conducive to legislation, industrial standards, tax compliance and promotion through media (Chan and Chong 2012; Lin and Ho 2009) of the new technology. The literature of innovative technology confirms the effect of government support on adoption (Hwang et al. 2016; Lin et al. 2018; 
Osakwe et al. 2016) . Under the "Make in India" scheme, the Indian government is providing incentives for research and development and tax benefits on research product outcomes in the automotive manufacturing sector (Chouhan et al. 2017). The Automotive Mission Plan 201626 (AMP 2026) formulates the collective governmental vision towards automotive sector growth, technological maturity, contribution to national development, institutional structure and global competitiveness (Chouhan et al. 2017). InRos Technology is in its emerging stage in the ACMCs in India (Sangani 2019). As the government is developing and promoting many initiatives that might affect the adoption of InRos positively, we formulate the ensuing hypothesis:

H6: Government support for InRos positively affects the adoption of InRos in ACMCs.

\section{Adoption intention and Potential use}

Organisations are ready to invest in new technologies when they feel that the new technology is required for their business functions (Oliveira et al. 2019). Extant literature has dealt with various stages of adoption of new technologies (Chong and Chan 2012; Hossain et al. 2017b; Puklavec et al. 2018). In this study, the potential use of InRos means the perceived capability of the organisation (Schmidt et al. 2015) to implement the InRos for manufacturing. Though an ACMC may intend to adopt new technology such as InRos, it is not necessary that the ACMC has the capacity to implement the InRos for manufacturing. Therefore, we suggest that the relationship between adoption intention and potential use can be examined in the context of InRos for ACMCs as follows:

H: Adoption Intention of InRos positively affects the potential use of InRos in ACMCs.

\section{Moderating effect of cost issues between adoption intention and potential use}


InRos is a new technology that requires the related platforms, control systems, safety enclosures, mounting arrangements, all of which involve a high cost (Sangomla 2019). Installation and configuration of InRos also require a huge amount of investment from organisations (Steven 2019). Indian ACMCs have a deficiency of funds and low investment capacity to invest in InRos (Economic Times 2019). Perceived cost issues are understood as barriers and influence negatively the adoption of innovative technology (Maduku et al. 2016; Reyes et al. 2016). In this work, the authors intend to study the moderating effect of perceived cost issues on the relationship between adoption intention and potential use of InRos technology. Many ACMCs in India prefer to use human labor for manufacturing, which is more cost-effective than incurring the high implementation cost of InRos (Economic Times 2019). Though ACMC firms intend to adopt new technologies such as InRos for manufacturing, this might affect their potential use due to perceived cost issues. Therefore, the below hypothesis is formulated:

$H_{8}:$ Perceived cost issues moderate the relation between the Adoption Intention and the potential use of InRos in ACMCs.

\section{Research Methodology}

This study leveraged quantitative methods. In-person face-to-face, online and telephone survey methods were deployed as they helped researchers save time and also overcome the geographic distance limitations (and related budget demands). Research instrument design, sampling and data collection were developed and performed to investigate the relationships between the variables in the proposed research model. The key dependent variables to be tested in the proposed model are InRos Adoption Intention (ADN) and ultimately Potential Use of InRos (PTU).

\section{Research Instrument Design}


The existing literature of TOE was utilised to design the research instrument to examine the InRos adoption in ACMCs. The measurement scale was adapted from existing literature in the TOE area and innovative technology adoption (Abramowicz 2015; Al-Qirim 2006; Awa et al. 2017; Ghobakhloo et al. 2011; Grant 1991; Lin 2014; Lin and Ho 2009; Lin et al. 2018; Maduku et al. 2016; Oliveira and Martins 2010; Reyes et al. 2016; Sackey and Bester 2016; Wei et al. 2015). The validity of the constructs and reliability of the scale (Fornell and Larcker 1981) was verified for all the constructs.

Five subject matter experts were identified from the Auto Component Manufacturing Association of India (ACMA) and senior officials from the 'Make in India' Scheme. Before the collection of data, the scope and objectives of the research were explained and discussed with them. The face validity was confirmed by considering and incorporating the suggestions of the subject matter experts and subsequently, the pre-test questionnaire was prepared. The constructs were measured using a five-point Likert scale.

The list of ACMCs was taken from the ACMA database, including more than 800 firms in India. The ACMCs where advanced technology similar to InRos such as Industrial IoT, Computer vision, Blockchain, Artificial Intelligence, Augmented reality, was used for the manufacturing process were chosen randomly for this research. The pre-test survey was conducted by interviewing 30 managers, technology officers and owners of ACMCs using the preliminary questionnaire. A few minor revisions in the questionnaire were made considering the feedback from the respondents; the Cronbach's alpha was utilised to check the internal consistency and reliability. Pilot tests were conducted among 110 respondents and the analysis of data was completed using PLS-SEM. The collection of main data was completed after satisfactory results were derived from the pilot test. Table 2 shows the constructs operationalised.

Table 2: Operationalization of Constructs 


\begin{tabular}{|c|c|c|c|c|}
\hline Main Construct & Type & $\begin{array}{l}\text { Factor } \\
\text { Loading }\end{array}$ & Indicators / items & Reference \\
\hline \multicolumn{5}{|l|}{ Technology } \\
\hline \multirow{4}{*}{$\begin{array}{l}\text { Perceived } \\
\text { Compatibility } \\
\text { (PCM) } \\
\text { AVE }=0.741 \\
\text { CR }=0.903 \\
\alpha=0.802\end{array}$} & \multirow[t]{4}{*}{ Reflective } & 0.887 & $\begin{array}{l}\text { InRos would be appropriate for the current } \\
\text { technology in our organisation. }\end{array}$ & \multirow{4}{*}{$\begin{array}{l}\text { (Awa et al. } \\
\text { 2017; Al- } \\
\text { Qirim 2006) }\end{array}$} \\
\hline & & 0.877 & $\begin{array}{l}\text { InRos would be suitable for our work processes and } \\
\text { practices in the organisation. }\end{array}$ & \\
\hline & & 0.874 & InRos would be appropriate for our work culture. & \\
\hline & & 0.882 & $\begin{array}{l}\text { InRoswould be based on our norms, values, systems } \\
\text { and philosophies at our organisation. }\end{array}$ & \\
\hline \multirow{5}{*}{$\begin{array}{l}\text { Perceived } \\
\text { Benefits (PBT) } \\
\text { AVE }=0.708 \\
\text { CR }=0.860 \\
\alpha=0.829\end{array}$} & & 0.821 & InRos improve sales' revenue. & \multirow{5}{*}{$\begin{array}{l}\text { (Lin 2014; } \\
\text { Oliveira and } \\
\text { Martins } \\
2010)\end{array}$} \\
\hline & & 0.857 & $\begin{array}{l}\text { InRos improve the overall productivity of the } \\
\text { manufacturing process. }\end{array}$ & \\
\hline & & 0.829 & InRos provides more speed in production. & \\
\hline & & 0.889 & InRos allows to achieve a competitive advantage. & \\
\hline & & 0.890 & $\begin{array}{l}\text { InRos could provide a defect-free and accurate } \\
\text { product manufacturing. }\end{array}$ & \\
\hline \multicolumn{5}{|c|}{ p } \\
\hline \multirow{5}{*}{$\begin{array}{l}\text { IT Infrastructure } \\
\text { (INF) } \\
\text { AVE }=0.711 \\
\text { CR }=0.893 \\
\alpha=0.809\end{array}$} & \multirow[t]{5}{*}{ Reflective } & 0.837 & $\begin{array}{l}\text { I feel that the necessary physical IT infrastructure is } \\
\text { available in our organisation for InRos. }\end{array}$ & \multirow{5}{*}{$\begin{array}{l}\text { (Grant 1991; } \\
\text { Wei et al. } \\
\text { 2015) }\end{array}$} \\
\hline & & 0.828 & $\begin{array}{l}\text { I feel that the staff would be equipped with the } \\
\text { managerial and technical skills required for InRos. }\end{array}$ & \\
\hline & & 0.840 & $\begin{array}{l}\text { In our organisation, experience and skills of human } \\
\text { resources are rooted in policies, repositories of } \\
\text { information and processes. }\end{array}$ & \\
\hline & & 0.846 & $\begin{array}{l}\text { I feel that across the various departments of the } \\
\text { organisation, we would be capable of sharing } \\
\text { resources of InRos. }\end{array}$ & \\
\hline & & 0.835 & $\begin{array}{l}\text { Our organisation can foresee the customer needs in } \\
\text { this technology-driven manufacturing market. }\end{array}$ & \\
\hline \multicolumn{5}{|l|}{ Environment } \\
\hline \multirow{4}{*}{$\begin{array}{l}\text { External } \\
\text { Pressure (EPR) } \\
\text { AVE }=0.759 \\
C R=0.902 \\
\alpha=0.799\end{array}$} & \multirow[t]{4}{*}{ Reflective } & 0.882 & $\begin{array}{l}\text { We have to improve productivity, as customers } \\
\text { demand it. }\end{array}$ & \multirow{4}{*}{$\begin{array}{l}\text { (Reyes et al. } \\
\text { 2016; Lin et } \\
\text { al. 2018) }\end{array}$} \\
\hline & & 0.828 & $\begin{array}{l}\text { We have pressure from customers to provide } \\
\text { accurate and defect-free products. }\end{array}$ & \\
\hline & & 0.827 & $\begin{array}{l}\text { We have pressure from customers to speed up the } \\
\text { production and delivery of products. }\end{array}$ & \\
\hline & & 0.819 & $\begin{array}{l}\text { We have to always compete with competitors with } \\
\text { new technology such as InRos. }\end{array}$ & \\
\hline \multirow{4}{*}{$\begin{array}{l}\text { Support from } \\
\text { InRos Vendors } \\
(\mathrm{SPV}) \\
\mathrm{AVE}=0.706 \\
\mathrm{CR}=0.851 \\
\alpha=0.804\end{array}$} & \multirow[t]{4}{*}{ Reflective } & 0.813 & $\begin{array}{l}\text { InRos vendors would technically support the ACMC } \\
\text { companies. }\end{array}$ & \multirow{4}{*}{$\begin{array}{l}\text { (Ghobakhloo } \\
\text { et al. 2011; } \\
\text { Maduku et } \\
\text { al. 2016) }\end{array}$} \\
\hline & & 0.806 & $\begin{array}{l}\text { InRos vendors would provide the necessary training } \\
\text { of InRos operations for ACMCs }\end{array}$ & \\
\hline & & 0.802 & $\begin{array}{l}\text { InRos vendors give free trainings for marketing } \\
\text { InRos. }\end{array}$ & \\
\hline & & 0.812 & InRosmarketing is actively done by InRos vendors. & \\
\hline \multirow{2}{*}{$\begin{array}{l}\text { Government } \\
\text { support }(\mathrm{GSP}) \\
\mathrm{AVE}=0.738 \\
\mathrm{CR}=0.879\end{array}$} & \multirow[t]{2}{*}{ Reflective } & 0.848 & $\begin{array}{l}\text { The government financially supports the InRos } \\
\text { technology. }\end{array}$ & \multirow{2}{*}{$\begin{array}{l}\text { (Lin and Ho } \\
\text { 2009; Lin et } \\
\text { al. 2018) }\end{array}$} \\
\hline & & 0.812 & $\begin{array}{l}\text { The government encourages companies to suggest } \\
\text { and apply InRos projects for funding }\end{array}$ & \\
\hline
\end{tabular}




\begin{tabular}{|c|c|c|c|c|}
\hline \multirow[t]{2}{*}{$\alpha=0.851$} & & 0.897 & $\begin{array}{l}\text { The government provides training for InRos related } \\
\text { skills. }\end{array}$ & \\
\hline & & 0.804 & InRos norms are supported by Government. & \\
\hline \multirow{3}{*}{$\begin{array}{l}\text { Adoption } \\
\text { Intention }(\mathrm{ADN}) \\
\mathrm{AVE}=0.744 \\
\mathrm{CR}=0.897 \\
\alpha=0.806\end{array}$} & \multirow[t]{3}{*}{ Reflective } & 0.876 & $\begin{array}{l}\text { Organisation is ready to invest in resources to adopt } \\
\text { InRos. }\end{array}$ & \multirow[t]{3}{*}{$\begin{array}{l}\text { (Oliveira et } \\
\text { al. 2019) }\end{array}$} \\
\hline & & 0.831 & Business activities in ACMCs require InRos. & \\
\hline & & 0.854 & $\begin{array}{l}\text { InRos is required for different tasks at our } \\
\text { organisation. }\end{array}$ & \\
\hline \multirow{3}{*}{$\begin{array}{l}\text { Potential Use of } \\
\text { InRos (PTU) } \\
\text { AVE }=0.752 \\
\text { CR }=0.884 \\
\alpha=0.821\end{array}$} & \multirow[t]{3}{*}{ Reflective } & 0.873 & We propose to implement InRos in the near future. & \multirow{3}{*}{$\begin{array}{l}\text { ( Abramowic } \\
\text { 2015; } \\
\text { Sackey and } \\
\text { Bester 2016; } \\
\text { Lin et al. } \\
2018 \text { ) }\end{array}$} \\
\hline & & 0.876 & $\begin{array}{l}\text { We are inclined to increase use of advanced } \\
\text { technology such as InRos. }\end{array}$ & \\
\hline & & 0.848 & $\begin{array}{l}\text { We have capacity to use and implement InRos in our } \\
\text { organisation. }\end{array}$ & \\
\hline \multirow{3}{*}{$\begin{array}{l}\text { Perceived Cost } \\
\text { Issues (COI) } \\
\text { AVE }=0.701 \\
C R=0.902 \\
\alpha=0.834\end{array}$} & \multirow[t]{3}{*}{ Reflective } & 0.850 & Configuration cost of InRos is high. & \multirow{3}{*}{$\begin{array}{l}\text { (Reyes et al. } \\
2016)\end{array}$} \\
\hline & & 0.875 & InRos has high cost of installation. & \\
\hline & & 0.879 & $\begin{array}{l}\text { The platform, control systems safety enclosure and } \\
\text { mounting arrangement require huge investment for } \\
\text { InRos. }\end{array}$ & \\
\hline
\end{tabular}

\section{Sampling and Data Collection}

To determine the suitable sample size, the traditional rule of thumb was considered and adopted (Gefen et al. 2000). The largest construct in this model was identified and we derived the right sample size as being ten times the number of items considered. Therefore, 50 is the required sample size for this research. The primary data was collected by administering the final survey questionnaire shown in Table 2. The survey was carried out on the list of ACMCs taken from the ACMA database. The ACMCs were chosen where some kind of advanced technology similar to InRos was used for the manufacturing process. The automobile hubs in the states of Maharashtra, Tamil Nadu, Gujarat, Madhya Pradesh and the National Capital region were considered for data sampling. The random sampling method was used to collect the data from 480 ACMCs from the corresponding automobile hubs.

Along with online surveys, telephonic permission was asked prior to the company visit and then ACMCs were personally visited to conduct the survey. In these companies, technology managers, owners and production managers were surveyed. On completion of the survey, a total of 460 questionnaires were suitable for data analysis out of 720 questionnaires with a response rate of $63.8 \%$. The total data collection process took 14 months as data was collected 
from various automobile hubs and clusters in India. The data collection was done from the states of Maharashtra (24\%), Tamil Nadu (20\%), Gujarat (18\%), Madhya Pradesh (17\%) and the National Capital Region (21\%) in India constituting a total of 480 ACMCs that were surveyed.

Out of total ACMCs surveyed, 9\% have used AI-empowered InRos for more than six months and $7 \%$ for less than six months. Moreover, $84 \%$ ACMCs have been using mechanical industrial robots for more than a year along with some type of advanced manufacturing technology. The breakup of the sample is as follows: $29 \%$ are production managers, $35 \%$ Technology Heads/Managers, and 36\% owners and proprietors. 68\% of the companies are using advanced technologies and $32 \%$ are using automation technologies similar to InRos for other manufacturing functions.

\section{Non-response Bias}

A t-test was calculated to analyse the difference in the response between the early wave (270) and late wave (190) groups (Armstrong and Overton 1977; Tsou and Hsu 2015). The result $(\mathrm{p}=0.36)$ proved that non-response bias is not present. The total number of complete responses were 460 .

\section{Data Analysis}

\section{Common method bias and endogeneity}

The single factor Harman test (Abdallah et al. 2017; Podsakoff et al. 2003; Podsakoff and Organ 1986; Wang et al 2018) was performed to scrutinize common method bias presence. The variance explained by a single factor was $28.62 \%$, which is less than $50 \%$ indicating common method bias is not a concern in this research. Hence, the reliability and validity of the measures were assessed. Additionally, Recursivity in the structural model may cause endogeneity (Dubey et al. 2018; Lai et al. 2018). The variance in an exogenous variable may be endogenous to the model (Guide and Ketokivi 2015) as the cross-sectional data may result 
in a mis-specified model. Hence, a Ramsey regression equation error test was employed (Lai et al. 2018) and established that the endogeneity was not in the proposed model. Hence, the validity and reliability of the measures were established.

\section{PLS-SEM}

PLS-SEM is a variance-based path modeling method that has the capability to symbolize variables with multiple indicators in the study. PLS-SEM makes limited distributional assumptions of OLS regression (Chin, Peterson, and Brown 2008). PLS-SEM is employed to test conceptual models and causal relationships between the latent constructs and their indicators (Gudergan et al. 2008). Compared to the maximum likelihood method, PLS-SEM is a flexible method preferred to model constructs (Henseler and Chin 2010). PLS-SEM is employed in studies when the research purpose is the extension of the present theory (Hair et al. 2011). PLS-SEM has also been employed in innovative technology adoption studies (Akter et al. 2017; Almuraqab 2017; Cao et al. 2019; Delic and Eyers 2020; Jasimuddin et al. 2017; Rampasso et al. 2019). Hence, the data analysis was performed employing Smart PLS 2.0 (Ringle et al. 2005).

\section{Measurement model}

PLS-SEM was utilised for the analysis of the conceptual model. PLS-SEM is generally used in social science studies as it is appropriate for non-normal data and supports small as well as large sample sizes (Hair et al. 2014; Hair et al. 2017). The SmartPLS 2.0 software (Ringle et al. 2005) was applied for primary data analysis. The measurement properties in the final model were calculated for the latent constructs, reflective in nature, and having multiple indicators. The high internal consistency of all the constructs is confirmed as the value of Cronbach alpha was above 0.7 (Nunnally 1978). Based on Table 2, CR values confirm the high level of reliability and internal consistency of all the constructs as the outer loading for all the items were higher than the minimum beginning value of 0.6. The AVE values are greater than the 
minimum beginning value of 0.5 , so the convergent validity for all the constructs is proved (Guadagnoli and Velicer 1988; Hair et al. 2017; Wang, et al. 2013).

The comparison of the inter-correlations of the constructs with the AVE off-diagonal values as revealed in Table 3 proves the discriminant validity. Discriminant validity between the constructs is supported (Fornell and Larcker 1981), as the squared variance values were lower than the corresponding AVE.

Table 3. Discriminant Validity

\begin{tabular}{|l|l|l|l|l|l|l|l|l|l|}
\hline $\begin{array}{l}\text { Research } \\
\text { Construct }\end{array}$ & PCM & PBT & INF & EPR & SPV & GSP & ADN & PTU & COI \\
\hline PCM & $\mathbf{. 8 6 0}$ & & & & & & & & \\
\hline PBT & .677 & $\mathbf{. 8 4 1}$ & & & & & & & \\
\hline INF & .520 & .679 & $\mathbf{. 8 4 3}$ & & & & & & \\
\hline EPR & .404 & .501 & .497 & $\mathbf{. 8 7 1}$ & & & & & \\
\hline SPV & .389 & .483 & .477 & .580 & $\mathbf{. 8 4 0}$ & & & & \\
\hline GSP & .357 & .406 & .507 & .524 & .414 & $\mathbf{. 8 5 9}$ & & & \\
\hline ADN & .308 & .357 & .378 & .405 & .367 & .516 & $\mathbf{. 8 6 2}$ & & \\
\hline PTU & .298 & .321 & .420 & .388 & .397 & .408 & .209 & $\mathbf{. 8 6 7}$ & \\
\hline COI & .267 & .287 & .224 & .287 & .271 & .347 & .228 & .284 & $\mathbf{. 8 3 7}$ \\
\hline
\end{tabular}

\section{Structural Model}

The validity and reliability of the measurement model was established and then the path analysis was estimated using the structural equation model. The path coefficients and their significance level are illustrated in Table 4 and Figure 2.

\section{Figure 2. Structural model}




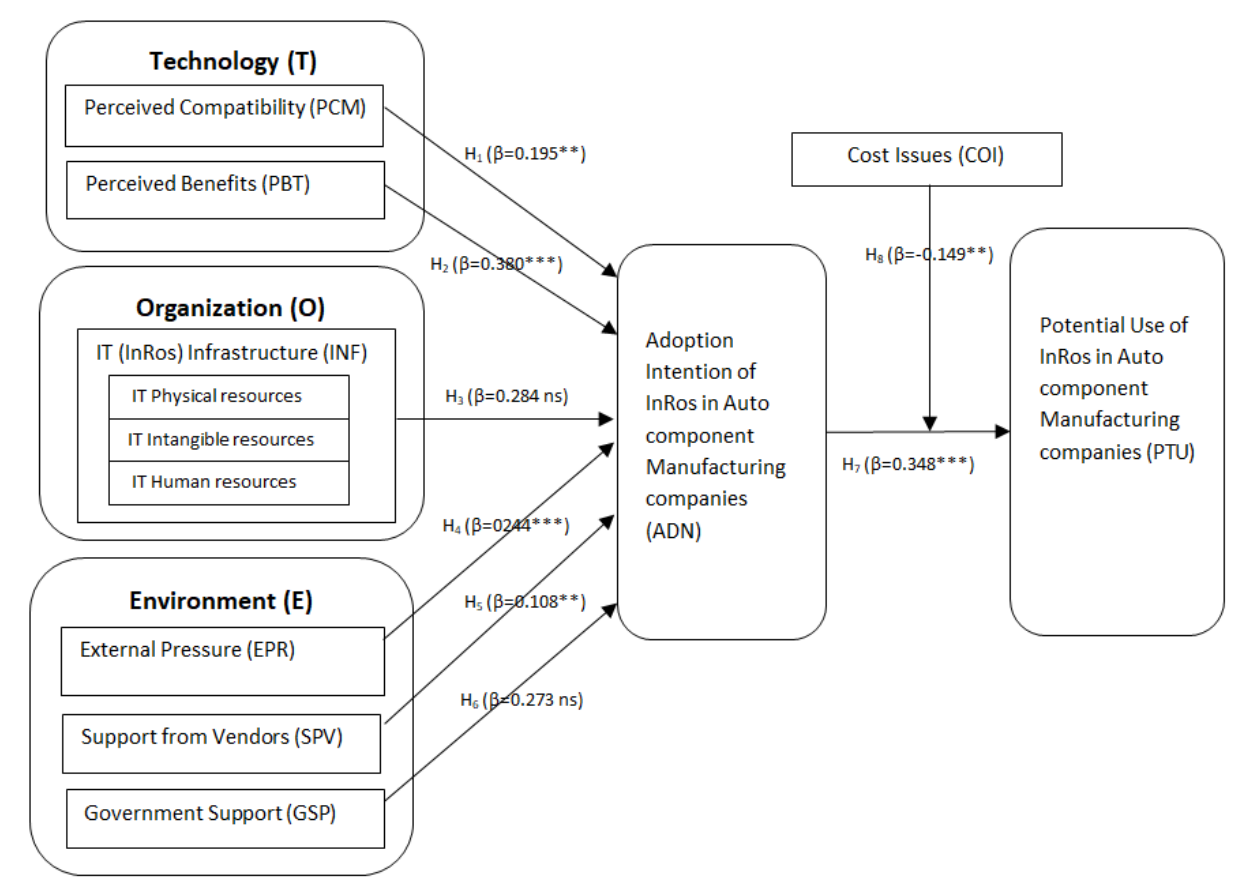

Table 4. Path Coefficient

\begin{tabular}{|c|c|c|c|}
\hline Hypothesis & Path & $\beta$ & T Statistics \\
\hline $\mathrm{H}_{1}$ & $\mathrm{PCM} \rightarrow \mathrm{ADN}$ & 0.195 & $2.033 * *$ \\
\hline $\mathrm{H}_{2}$ & $\mathrm{PBT} \rightarrow \mathrm{ADN}$ & 0.380 & $3.688 * * *$ \\
\hline $\mathrm{H}_{3}$ & $\mathrm{INF} \rightarrow \mathrm{ADN}$ & 0.284 & $1.616 \mathrm{~ns}$ \\
\hline $\mathrm{H}_{4}$ & $\mathrm{EPR} \rightarrow \mathrm{ADN}$ & 0.244 & $3.565 * * *$ \\
\hline $\mathrm{H}_{5}$ & $\mathrm{SPV} \rightarrow \mathrm{ADN}$ & 0.108 & $2.077 * *$ \\
\hline $\mathrm{H}_{6}$ & $\mathrm{GSP} \rightarrow \mathrm{ADN}$ & 0.273 & $1.292 \mathrm{~ns}$ \\
\hline $\mathrm{H}_{7}$ & $\mathrm{ADN} \quad \rightarrow$ PTU & 0.348 & $3.322 * * *$ \\
\hline $\mathrm{H}_{8}$ & $\mathrm{ADN}$ x COI $\rightarrow \mathrm{PTU}$ & -0.105 & $3.291 * * *$ \\
\hline
\end{tabular}

\section{Results}

The findings reveal that PCM $(\beta=0.195, \mathrm{p}<0.05)$ influences positively the and, which is in line with part of the previous literature (Awa and Ojiabo 2016) but contradicts a study of technology adoption in Nigeria (Awa et al. 2017). The PBT $(\beta=0.380, p<0.01)$ affects positively the ADN which is in line with present studies (Lin 2014; Oliveira and Martins 2010), as there are many benefits associated with the adoption of InRos in ACMCs. It is found that INF $(\beta=0.284$, n.s. $)$ has a non-significant relation with ADN which is not consistent with previous findings of an RFID-related study (Wei et al. 2015). As there are various types of new 
technologies deployed in ACMCs for manufacturing automation in addittion to InRos, organisations might not give much importance to IT physical infrastructure (Chau et al. 1991). Accordindly, it may well be that ACMCs are giving more importance to the benefits and compatibility of InRos technology than the requirement of skilled people, synergy among various departments and physical infrastructure. EPR $(\beta=0.244, p<0.01)$ is strongly and positively influencing the ADN (Aboelmaged 2014; Guo et al. 2017; Hassan et al. 2017; Lin 2014) as ACMCs are facing stiff competition from global competitors and need to serve the global customers. The SPV $(\beta=0.108, \mathrm{p}<0.05)$ influences positively the ADN: this finding contradicts the study of mobile marketing adoption study (Maduku et al. 2016). InRos is an innovative and complex technology and ACMCs require assistance from vendors. GSP $(\beta=$ 0.273, n.s.) was found to be non-significant towards ADN of InRos (Oliveira et al. 2014). This finding contradicts most of the present literature (Hwang et al. 2016; Lin et al. 2018; Osakwe et al. 2016). A plausible explanation for this contrasting finding might be that while schemes such as "Make in India" allow promoting manufacturing technology, there is scarce awareness of InRos among ACMC managers and strict government regulations make the relationship more complex and multifaceted, so that it is not possible to predict ex-ante if government support will enhance by itself the intention to adopt the focal technology (Chiu et al 2017; Hsu and Yeh 2017; Troshani et al. 2010). Though government has policies to promote InRo however due to political issues and the fear of loosing a number of jobs in ACMCs is not much promoting InRo schemes. As govnerment will have pressure of labour welfare of workers who will loose jobs due to adoption of InRo in ACMCs. Government needs to ensure the transition in assoctation with industry and reskilling workers (Dhakkapa 2017; Dhritiman 2018; Menifestias 2020). There is a lack of econsystem, high import duties imparted by government are impediments (Dhritiman 2018). Government regulations as not much advanced technology friendly (Dhritiman 2018) 
$\operatorname{ADN}(\beta=0.348, p<0.01)$ is the predictor of PTU of InRos in ACMCs. It is also found that the relationship between $\mathrm{ADN}$ and PTU is moderated by COI $(\beta=-0.105, \mathrm{p}<0.01)$ and COI negatively influences the relationship of ADN and PTU.

\section{Discussion}

In this research, we examined the predictors of adoption intention and potential use of InRos in ACMCs. In today's competitive environment, ACMCs have to adopt new technologies to survive in the marketplace. The respondents feel that their organisations have appropriate work culture, processes, practices, values and systems to adopt InRos. They also mention the appropriateness of InRos in line with the current technologies utilised in their organisations. InRos require unique and customized programming due to the features that the products of the ACMCs need to display and are utilised for various production processes such as assembling, painting, welding, packaging, testing and inspection of production (Graetz and Michaels 2018). PCM explains the integration and fitting of InRos with current equipment in the manufacturing ACMCs.

We found that PCM is a good predictor of the adoption of InRos in ACMCs. There are many benefits pertaining to the adoption of InRos such as improved production, improved sales revenue, reduced manpower cost, accurate and defect-free products, and higher likelihood to achieve a sustained competitive advantage for ACMCs active in the market (Soffar 2019). Therefore, managers perceive that InRos are beneficial to ACMC organisations and they would adopt them. IT infrastructure in this research discusses the physical IT infrastructure, employee/staff technical and managerial skillsets, current repositories of information and processes, co-ordination between the departments and foresightedness of managers towards the customer needs.

We found that INF is not a significant predictor of ADN. This suggests that ACMCs need to upgrade with the physical IT infrastructure as the latter is not up to the mark. InRos is a new 
technology in India; hence, there is not much skilled manpower available in the ACMCs. Even many of the ACMCs in India still prefer to use traditional labour-based manufacturing workforce rather than InRos technology (Economic Times 2019), which shows the dearth of managerial skillsets that suggest that apparently, managers do not totally understand InRos technology for production and manufacturing of auto-components. The current information repositories and processes would also need an upgrade as InRos is an advanced and sophisticated technology.

External pressure is faced by the ACMCs due to the globalization of the Indian automobile sector. In India, many global customers exist and they expect the usage of advanced technology in manufacturing for accurate and fast production. ACMCs face pressure not just from the competitors but also from customers' demand for quick delivery of the auto components and products. To be competitive in the market, ACMC organisations need to adopt advanced technologies (Sangani 2019). External pressure influences the InRos adoption which is in line with present research (Aboelmaged 2014; Guo et al. 2017; Hassan et al. 2017; Lin 2014).

In this technology-driven manufacturing environment, InRos vendors are strongly marketing InRos to ACMCs. Managers feel that training and continuous support from InRos vendors are required for better adoption of InRos. Hence, SPV influences the InRos adoption by ACMCs. Contrarily to the expected results, government support (GSP) was not found to be statistically significant towards ADN of InRos in ACMCs, although the government is providing many incentives through the "Make in India" program and AMP 2026. The explanation of this phenomenon could stem from the diminishing enthusiasm of the ACMCs to comply with the governmental norms due to the obstacles and hindrances faced in the audit and compliance, with strict government regulations. The government could help ACMCs to adopt InRos by taking more initiatives to provide incentives and reduction of import duties of InRos, or promote InRos indigenous manufacturing in India. 
This study found that ADN is a predictor of potential use of InRos in ACMCs. Organisations' readiness to invest in InRos influences the capability of implementation and increases potential usage of InRos. However, there are perceived cost issues that moderate the relationship between the ADN and PTU significantly. As the cost of installation and configuration of InRos is very high and the safety systems, enclosures and mounting arrangements for InRos require huge investment, COI moderates negatively the relationship between ADN and PTU. This study uniquely finds that the potential use of InRos will be lessened due to the high cost of InRos IT physical infrastructure, installation and configuration costs.

\section{Theoretical implications}

From a theoretical perspective, this work makes several contributions. the majority of the research related to advanced industrial manufacturing technologies such as InRos is focused on developed countries in the West rather than emerging economies such as India. However, different environmental settings and cultural contexts may generate different results.

Second, this research makes a distinctive contribution to the body of literature on the innovation of new advanced technologies and InRos adoption in the production settings. This work explores the factors affecting the adoption intention and potential use of InRos leveraging the TOE framework. The TOE does not provide by itself the factors useful to analyse the problem at hand, and it categorizes the factors into the respective constructs where the adoption of the technology actually happens (Puklavec, Oliveira, and Popovič 2018). Third, and related to the previous point, this study offers a novel academic contribution to the research stream revolving around the application of TOE in adoption studies, as it shows that some resources - especially IT infrastructure- are not sufficient to explain the new technology adoption. Accordingly, we believe that the traditional TOE framework should be extended by incorporating other metrics that might proxy the value of resources such as the total assets and the number of employees. Therefore, future research focusing on technology adoption should reflect in their model 
specification a wider appreciation of resources by leveraging on the Resource-Based View theory of the firm (Barney 1991; 2001; Peteraf 1993). Future studies might also understand if InRos can represent a set of valuable, rare, difficult to imitate and non-substitutable resources in today's competitive auto component manufacturing industry, potentially capable of making those ACMCs endowed with them to attain a sustained competitive advantage due to the heterogeneity of their resources compared to those owned, controlled and leveraged by their competitors (Penrose 1958; Rumelt 1984; Wernerfelt 1984).

Fourth, governmental support was found to be non-significant towards ADN of InRos (Oliveira et al. 2014) and it contradicts the present studies (Hwang et al. 2016; Lin et al. 2018; Osakwe et al. 2016). GSP is not a signficant contributor as most of the ACMCs are not aware of the government schemes and even government taxation has created slowdown in the automation industry. Currently, the increased rate of Goods and Services Tax (GST) imposed by Government of India (GoI) and the automobile market slowdown is a major challenge for ACMCs. Though GoI has initiated the 'Skill India' program to train the workforce, still there is a dearth of skilled workforce for InRos adoption and its potential usage (Dhakkapa 2017; Dhritiman 2018; Menifestias 2020). There is a lack of incentives provided by GoI for research and development activities at ACMCs (ACMA 2019). Associations such as "All India Council for Robotics and Automation" (aicra.ac.in) and ACMA are helping ACMCs for automation by delivering government schemes and training the workforce.

Fifth, this work attempts to fill the research gap of InRos adoption literature (Müller-abdelrazeq et al. 2019; Turja and Oksanen 2019) by identifying InRos-related contextual factors in the TOE framework with an organisation's viewpoint. Moreover, this study empirically validated the theoretical model anchored in the TOE Framework incorporating the resource-based view theory. We also discuss the potential use of InRos in ACMCs which was not given much importance in earlier studies (Schmidt et al. 2015) as shown in Table 1. 
Sixth, this research takes further steps to study the influence of adoption intention on the potential use of InRos. It also empirically validates the moderation effect of perceived cost issues between $\mathrm{ADN}$ and PTU, which is a unique contribution as it was found that perceived cost issues negatively moderate the relation between ADN and PTU of InRos. This study contributes to the existing literature on the adoption of advanced IT manufacturing technologyInRos adoption in ACMCs. Building on TOE, the proposed research model helps to understand how TOE related constructs influence the adoption intention and potential use of InRos in ACMCs. The high explanatory power of the proposed validated model with independent variables explaining InRos ADN of $68.9 \%\left(\mathrm{R}^{2}=.689\right)$ and PTU of $62.2 \%\left(\mathrm{R}^{2}=.622\right)$ represents a valuable contribution to the existing body of InRos literature.

\section{Managerial Implications}

This work highlights the factors affecting the adoption of InRos and subsequently its potential use which can be considered by B-2-B marketers to formulate marketing strategies for InRos in ACMCs. The findings of this work confirm that perceived compatibility, perceived benefits, external pressure, support from vendors are significant predictors of InRos adoption intention. The study also revealed that IT infrastructure and government support do not influence InRos adoption intention. Furthermore, it was found that perceived cost issues negatively moderate the relationship between the adoption intention and potential use of InRos.

The designers, manufacturers and marketers of InRos can understand the factors affecting the adoption intention of InRos and define suitable strategies to manufacture and market InRos. The designers and manufacturers should consider the compatibility of InRos with current manufacturing processes and systems in the organisation. This shall be useful for aligning InRos with the current production systems.Marketers and manufacturers should ensure continuous training and support to ACMCs as InRos is a new technology and employees are not much well versed with it. Even marketers should provide free training and demonstrations 
to understand the InRos benefits as perceived benefits are an important antecedent of InRos' adoption. The InRos marketers should also provide the testimonials of existing customers that successfully adopted InRos to promote them and built good perception about vendor support among ACMC managers. The marketers can highlight the InRos adoption benefits to ACMCs such as lower workforce cost, seamless production planning along with improved and accurate production by minimizing the defects.

Managers of ACMCs would understand the factors of adoption from this research. The IT infrastructure was not found significant which confirms that the IT infrastructure is not up to the mark in these ACMCs. The InRos is an advanced technology which requires new skillsets and IT infrastructure which ACMCs must embrace to facilitate the InRos Adoption.

Government support was found not significant, although the government is providing many incentives through the "Make in India" program and AMP 2026. The GoI and policymakers need to investigate the awareness among the ACMCs about these schemes and benefits provided by the government for InRos. If the government takes more initiatives towards providing incentives and reduction of import duties of InRos or promote InRos indigenous manufacturing in India it would help ACMCs to adopt InRos. A skilled workforce and better InRos infrastructure would help in accurate, low-cost and efficient production.

The adoption intention influences the potential use of InRos. However, the perceived cost issues negatively moderate the relationship between adoption intention and Potential use of InRos. The perceived cost issues faced by ACMCs are due to the high cost of infrastructure, maintenance of InRos infrastructure and high import duty for InRos purchase from other countries. Perceived cost issues are limiting the InRos potential use in ACMCs. The government can play a vital role in reducing the cost of InRos by promoting indigenous manufacturing of InRos in India or reducing the import duties. 
Policymakers need to devise policies that would promote the InRos adoption as InRos has many benefits that would improve the faster and accurate production at ACMCs. More specifically, Indian policymakers are encouraged to frame policies and regulatory frameworks that might provide incentives to ACMCs to increasingly adopt InRos which might generate positive effects on industrial production planning, productivity and national GDP.

\section{Conclusion}

InRos is an advanced technology that can be utilised for manufacturing in ACMCs. InRos boost the productivity by automation of various activities in the manufacturing process. It also improves the return on investment. It is imperative for ACMCs to adopt InRos to be competitive in this technology-driven manufacturing era. The research sought to examine the antecedents of InRos adoption intention and potential use of InRos in ACMCs. The model was developed incorporating the resource-based view in the traditional TOE framework by surveying 460 valid respondents of ACMCs. Perceived compatibility, perceived benefits, external pressure, support from vendors were found to be significant predictors of InRos adoption intention. It was also revealed that IT infrastructure and government support do not influence the InRos adoption intention. Further, it was found that perceived cost issues negatively moderate the relationship between the adoption intention and potential use of InRos in ACMCs.

\section{Limitations and Further Research}

This study displays a few limitations. First, as the empirical setting is a specific country (i.e., India), the implications of this work are mainly related to the observed emerging economy. However, the drivers of adoption of InRos may vary across different geographic regions or counties. Second, the research model might be enriched by embedding more constructs and 
variables such as anthropomorphism, trust, organisational fit, security, perceived values and additional control variables such as firm size and type of industry. Third, further investigations can be conducted to examine the adoption of InRos in various sectors and industries, for instance by examining how they are being embedded into service sectors (Mariani and Borghi 2019). Also, future studies can be carried out on the assimilation, implementation and actual usage along with the issues related to actual usage of InRos. Last, future scholars might embrace the most recent versions of the RBV theory of the firms, including those that focus on dynamic capabilities (Teece et al. 1997) to shed more light on how the adoption of InRos might be affected by a well-developed set of firm's dynamic capabilities allowing the manufacturing firms not only to boost their efficiency, effectiveness and performance but also to sense and seize business opportunities and to maintain competitiveness by reconfiguring existing resources. 


\section{References}

Abdallah, Ali, Yogesh K Dwivedi, and Nripendra P Rana. 2017. "International Journal of Information Management Factors Influencing Adoption of Mobile Banking by Jordanian Bank Customers : Extending UTAUT2 with Trust." International Journal of Information Management 37 (3): 99-110. doi:10.1016/j.ijinfomgt.2017.01.002.

Aboelmaged, Mohamed Gamal. 2014. "Predicting E-Readiness at Firm-Level: An Analysis of Technological, Organizational and Environmental (TOE) Effects on e-Maintenance Readiness in Manufacturing Firms." International Journal of Information Management 34 (5): 639-51. doi:10.1016/j.ijinfomgt.2014.05.002.

ACMA. 2019. "Indian Auto Component Industry Performance Review-FY 18." ACMC. file:///C:/Users/Admin/Downloads/ACMA-Presentation_press-conference_2019.pdf.

Al-Qirim, Nabeel. 2006. "The Role of the Government and E-Commerce Adoption in Small Businesses in New Zealand." International Journal of Internet and Enterprise Management 4 (4): 293. doi:10.1504/ijiem.2006.011042.

- 2007. "The Adoption of ECommerce Communications and Applications Technologies in Small Businesses in New Zealand." Electronic Commerce Research and Applications 6 (4): 462-73. doi:10.1016/j.elerap.2007.02.012.

Alaiad, Ahmad, and Lina Zhou. 2014. "The Determinants of Home Healthcare Robots Adoption: An Empirical Investigation." International Journal of Medical Informatics 83 (11): 825-40. doi:10.1016/j.ijmedinf.2014.07.003.

Alshamaila, Yazn, Savvas Papagiannidis, and Feng Li. 2013. "Cloud Computing Adoption by SMEs in the North East of England: A Multi-Perspective Framework." Journal of Enterprise Information Management 26 (3): 250-75. doi:10.1108/17410391311325225.

Armbruster, Heidi, Steffen Kinkel, Gunter Lay, and Spomenka Maloca. 2005. "TechnoOrganisational Innovation in the European Manufacturing Industry." European Manufacturing Survey. https://ref.sabanciuniv.edu/sites/ref.sabanciuniv.edu/files/emis_bulletin_1.pdf.

Armstrong, J. Scott, and Terry Overton. 1977. "Estimating Nonresponse Bias in Mail Surveys Estimating Nonresponse Bias in Mail Surveys.” Journal of Marketing Research 14 (3): 396-402. doi:10.1177/002224377701400320.

Awa, Hart O., and Ojiabo Ukoha Ojiabo. 2016. "A Model of Adoption Determinants of ERP within T-O-E Framework." Information Technology and People 29 (4): 901-30. doi:10.1108/ITP-03-2015-0068.

Awa, Hart O., Ojiabo Ukoha Ojiabo, and Longlife E. Orokor. 2017. "Integrated TechnologyOrganization-Environment (T-O-E) Taxonomies for Technology Adoption." Journal of Enterprise Information Management 30 (6): 893-921. doi:10.1108/JEIM-03-2016-0079.

Awa, Hart O., Ojiabo Ukoha, and Bartholomew C. Emecheta. 2016. "Using T-O-E Theoretical Framework to Study the Adoption of ERP Solution." Cogent Business and Management 3 (1). Cogent: 1-23. doi:10.1080/23311975.2016.1196571.

Awa, Hart O., Ojiabo Ukoha, and Sunny R. Igwe. 2017. "Revisiting Technology-OrganizationEnvironment (T-O-E) Theory for Enriched Applicability." Bottom Line 30 (1): 2-22. doi:10.1108/BL-12-2016-0044.

Baker, J. (in Y. Dwivedi, M. Wade, \& S. Schneberger (Eds.). 2011. The TechnologyOrganization-Environment Framework. In Information Systems Theory: Explaining and Predicting Our Digital Society. Springer. New York.

Barney, Jay. 1991. "Firm Resources and Sustained Competitive Advantage." Journal of Management 17 (1): 99-120. doi:10.1177/014920639101700108.

—. 2001. "Resource-Based Theories of Competitive Advantage: A Ten- Year Retrospective on the Resource-Based View." Journal of Management 27 (2001): 643- 
650. doi:10.1177/014920630102700602.

Belanche, Daniel, Luis V. Casaló, and Carlos Flavián. 2019. "Artificial Intelligence in FinTech: Understanding Robo-Advisors Adoption among Customers." Industrial Management and Data Systems 119 (7): 1411-30. doi:10.1108/IMDS-08-2018-0368.

Bharadwaj, Anandhi. 2011. "A Resource-Based Perspective on Information Technology Capability and Firm Performance: An Empirical Investigation." Management Information Systems 24 (1): 169-96. doi:10.2307/3250983.

Bibby, Lee, and Benjamin Dehe. 2018. "Defining and Assessing Industry 4.0 Maturity LevelsCase of the Defence Sector." Production Planning and Control 29 (12): 1030-43. doi:10.1080/09537287.2018.1503355.

Biswas Dhritiman. 2018. "The Policy Hack: What's Stopping i (Ndustrial)Robots." The Economic Times. $\quad$ https://economictimes.indiatimes.com/smallbiz/startups/newsbuzz/the-policy-hack-whats-stoppingindustrialrobots/articleshow/65729206.cms.

Brady, M., Gerhardt, L. A., \& Davidson, H. F. (Eds.). 2012. Robotics and Artificial Intelligence (Vol. 11). Italy: NATO ASI Series, Springer Science \& Business Media.

Bröhl, Christina, Jochen Nelles, Christopher Brandl, and Alexander Mertens. 2016. "TAM Reloaded: A Technology Acceptance Model for Human-Robot Cooperation in Production Systems." In International Conference on Human-Computer Interaction, 97103. Berlin: Springer Berlin Heidelberg. doi:10.1007/978-3-319-40548-3.

Cao, D., H. Tao, Y. Wang, A. Tarhini, and S. Xia. 2019. "Acceptance of Automation Manufacturing Technology in China: An Examination of Perceived Norm and Organizational Efficacy." Production Planning and Control 31 (8): 1-13. doi:10.1080/09537287.2019.1669091.

Chan, Felix T.S., and Alain Y.L. Chong. 2012. "A SEM-Neural Network Approach for Understanding Determinants of Interorganizational System Standard Adoption and Performances." Decision Support Systems 54 (1): 621-30. doi:10.1016/j.dss.2012.08.009.

Chau, Patrick Y K, Kar Yan Tam, and Kar Yan Tam. 1991. "Factors Affecting the Adoption of Open Systems : An Exploratory." MIS Quarterly 21 (1): 1-24. doi:10.2307/249740.

Cheng, Hong, Ruixue Jia, Dandan Li, and Hongbin Li. 2019. "The Rise of Robots in China." Journal of Economic Perspectives 33 (2): 71-88. doi:10.1257/jep.33.2.71.

Chin, Wynne W., Robert A. Peterson, and Steven P. Brown. 2008. "Structural Equation Modeling in Marketing: Some Practical Reminders." Journal of Marketing Theory and Practice 16 (4): 287-98. doi:10.2753/MTP1069-6679160402.

Chiu, Chui-Yu, Shi Chen, and Chun-Liang Chen. 2017. "An Integrated Perspective of TOE Framework and Innovation Diffusion in Broadband Mobile Applications Adoption by Enterprises." International Journal of Management, Economics and Social Sciences (IJMESS) 6 (1): 14-39. doi:http://hdl.handle.net/10419/157921.

Choi, Moon Jong, Sanghyun Kim, and Hyunsun Park. 2018. "Empirical Study on the Factors Influencing Process Innovation When Adopting Intelligent Robots at Small- and MediumSized Enterprises-The Role of Organizational Supports." Information (Switzerland) 9 (12). doi:10.3390/info9120315.

Chong, Alain Yee Loong, and Felix T.S. Chan. 2012. "Structural Equation Modeling for MultiStage Analysis on Radio Frequency Identification (RFID) Diffusion in the Health Care Industry." Expert Systems with Applications $39 \quad$ (10): 8645-54. doi:10.1016/j.eswa.2012.01.201.

Chouhan, Swarnima, Priyanka Mehra, and Ankita Daso. 2017. "India's Readiness for Industry 4.0 - $\quad$ A $\quad$ Focus on Automotive Sector." http://www.grantthornton.in/insights/articles/indias-readiness-for-industry-4.0--a-focuson-automotive-sector/. 
Dauth, Wolfgang, Sebastian Findesien, Jens Sudekum, and Nicole Wober. 2017. "German Robots: The Impact of Industrial Robots on Workers." Iab. http://doku.iab.de/discussionpapers/2017/dp3017.pdf.

Davila Delgado, Juan Manuel, Lukumon Oyedele, Anuoluwapo Ajayi, Lukman Akanbi, Olugbenga Akinade, Muhammad Bilal, and Hakeem Owolabi. 2019. "Robotics and Automated Systems in Construction: Understanding Industry-Specific Challenges for Adoption." Journal of Building Engineering 26 (January). Elsevier Ltd: 100868. doi:10.1016/j.jobe.2019.100868.

Delic, Mia, and Daniel R. Eyers. 2020. "The Effect of Additive Manufacturing Adoption on Supply Chain Flexibility and Performance: An Empirical Analysis from the Automotive Industry." International Journal of Production Economics 228. Elsevier B.V. doi:10.1016/j.ijpe.2020.107689.

Depietro, R., E. Wiarda, and M Fleischer. 1990. "The Context for Change: Organization, Technology and Environment.” The Processes of Technological Innovation 199 (0): 15175.

Dhakkapa, Bhargav. 2017. "How to Handle the Robot Invasion of Human Labour?" The Hindu. https://www.thehindu.com/thread/economy/should-we-consider-taxingrobots/article19949121.ece.

Dhawan, Rajat, Shivanshu Gupta, Neeraj Huddar, Bajalji Iyer, Ramesh Mangaleshwaran, and Asutosh Padhi. 2018. "The Auto Component Industry in India : Preparing for the Future." https://www.mckinsey.com/featured-insights/asia-pacific/the-auto-component-industryin-india-preparing-for-the-future\#: :text=a promising future\&text=The Indian automotive OEM industry, $76 \mathrm{mn}$ vehicles $\% 2 \mathrm{C}$ across segments.

Duan, Y., Edwards, J. S., \& Dwivedi, Y. K. 2019. “Artificial Intelligence for Decision Making in the Era of Big Data-Evolution, Challenges and Research Agenda." International Journal of Information Management 48: 63-71. doi:10.1016/j.ijinfomgt.2019.01.021.

Dubey, Rameshwar, Zongwei Luo, Angappa Gunasekaran, Shahriar Akter, Benjamin T. Hazen, and Matthew A. Douglas. 2018. "Big Data and Predictive Analytics in Humanitarian Supply Chains." The International Journal of Logistics Management 29 (2): 485-512. doi:10.1108/IJLM-02-2017-0039.

Dwivedi, Yogesh K., Laurie Hughes, Elvira Ismagilova, Gert Aarts, Crispin Coombs, Tom Crick, Yanqing Duan, et al. 2019. “Artificial Intelligence (AI): Multidisciplinary Perspectives on Emerging Challenges, Opportunities, and Agenda for Research, Practice and Policy." International Journal of Information Management, no. August: 0-1. doi:10.1016/j.ijinfomgt.2019.08.002.

Fornell, C. and Larcker, D.F. 1981. "Evaluating Structural Equation Models with Unobservable Variables and Measurement Error." Journal of Marketing Research 18 (1): 39-50. doi:10.2307/3151312.

Fosso Wamba, Samuel, Angappa Gunasekaran, Mithu Bhattacharya, and Rameshwar Dubey. 2016. "Determinants of RFID Adoption Intention by SMEs: An Empirical Investigation." $\begin{array}{lllll}\text { Production Planning and Control } 27 & \text { (12): 979-90. }\end{array}$ doi:10.1080/09537287.2016.1167981.

Gefen, David, Detmar Straub, and Marie-Claude Boudreau. 2000. "Communications of the Association for Information Systems Structural Equation Modeling and Regression: Guidelines for Research Practice." Communications of the Association for Information Systems 4 (1): 1-77. doi:10.17705/1CAIS.00407.

Ghobakhloo, Morteza, Daniel Arias-Aranda, and Jose Benitez-Amado. 2011. Adoption of ECommerce Applications in SMEs. Industrial Management and Data Systems. Vol. 111. doi:10.1108/02635571111170785.

Graetz, George, and Guy Michaels. 2018. "Robots at Work." The Review of Economics and 
Statistics c (5): 753-68. doi:10.1162/REST.

Grant, R. M. 1991. "The Resource-Based Theory of Competitive Advantage: Implications for Strategy Formulation." California Management Review 33 (3): 114-35. 10.1016/B978-07506-7088-3.50004-8.

Grover, P., Kar, A. K., \& Dwivedi, Y. K. 2020. "Understanding Artificial Intelligence Adoption in Operations Management: Insights from the Review of Academic Literature and Social Media Discussions." Annals of Operations Research, 1-37. doi:10.1007/s10479-020-03683-9.

Grover, Varun. 1993. "An Empirically Derived Model for the Adoption of Customer-based Interorganizational Systems.” Decision Sciences 24 (3): 603-40. doi:10.1111/j.15405915.1993.tb01295.x.

Guadagnoli, Edward, and Wayne F. Velicer. 1988. "Relation of Sample Size to the Stability of Component Patterns." Psychological Bulletin 103 (2): 265-75. doi:10.1037/00332909.103.2.265.

Gudergan, Siegfried P., Christian M. Ringle, Sven Wende, and Alexander Will. 2008. "Confirmatory Tetrad Analysis in PLS Path Modeling." Journal of Business Research 61 (12): 1238-49. doi:10.1016/j.jbusres.2008.01.012.

Guide, V. Daniel R., and Mikko Ketokivi. 2015. "Notes from the Editors: Redefining Some Methodological Criteria for the Journal." Journal of Operations Management 37: v-viii. doi:10.1016/S0272-6963(15)00056-X.

Guo, Yue, Qiong Jia, and Stuart Bar]mes. 2017. "Enterprise 2 . 0 Post-Adoption : Extending the Information System Continuance Model Based on The ..." Computers in Human Behavior 67 (November 2016): 95-105. doi:10.1016/j.chb.2016.10.022.

Gursoy, Dogan, Oscar Hengxuan Chi, Lu Lu, and Robin Nunkoo. 2019. "Consumers Acceptance of Artificially Intelligent (AI) Device Use in Service Delivery." International Journal of Information Management 49 (March): 157-69. doi:10.1016/j.ijinfomgt.2019.03.008.

Hair, J. F., Jr., Hult, G. T. M., Ringle, C. M., \& Sarstedt, M. 2017. A Primer on Partial Least Squares Structural Equation Modeling (2nd Ed.). Long Range Planning. Landon, UK: Sage Publication.

Hair, Joe F., Christian Ringle, and Marko Sarstedt. 2011. "PLS-SEM: Indeed a Silver Bullet." Journal of Marketing Theory and Practice 19 (2): 139-51. doi:10.2753/MTP10696679190202.

Hair, Joe F., Marko Sarstedt, Lucas Hopkins, and Volker G. Kuppelwieser. 2014. "Partial Least Squares Structural Equation Modeling (PLS-SEM): An Emerging Tool in Business Research.” European Business Review 26 (2): 106-21. doi:10.1108/EBR-10-2013-0128.

Hassan, Haslinda, Alexei Tretiakov, and Dick Whiddett. 2017. "Factors Affecting the Breadth and Depth of E- Procurement Use in Small and Medium Enterprises." Journal of Organizational Computing and Electronic Commerce 27 (4). Taylor \& Francis: 304-24. doi:10.1080/10919392.2017.1363584.

Hassan, Mayadah, Maged Ali, Emel Aktas, and Kholoud Alkayid. 2015. "Factors Affecting Selection Decision of Auto-Identification Technology in Warehouse Management: An International Delphi Study." Production Planning and Control 26 (12): 1025-49. doi:10.1080/09537287.2015.1011726.

Henderson, Dave, Steven D Sheetz, and Brad S Trinkle. 2012. "International Journal of Accounting Information Systems The Determinants of Inter-Organizational and Internal in-House Adoption of XBRL : A Structural Equation Model." International Journal of Accounting Information Systems 13 (2). Elsevier Inc.: 109-40. doi:10.1016/j.accinf.2012.02.001.

Henseler, Jörg, and Wynne W. Chin. 2010. “A Comparison of Approaches for the Analysis of 
Interaction Effects between Latent Variables Using Partial Least Squares Path Modeling." Structural Equation Modeling 17 (1): 82-109. doi:10.1080/10705510903439003.

Hossain, Mohammad Alamgir, Craig Standing, and Caroline Chan. 2017. "The Development and Validation of a Two-Staged Adoption Model of RFID Technology in Livestock Businesses." Information Technology and People 30 (4): 785-808. doi:10.1108/ITP-062016-0133.

Hsu, Ching Wen, and Ching Chiang Yeh. 2017. "Understanding the Factors Affecting the Adoption of the Internet of Things." Technology Analysis and Strategic Management 29 (9). Taylor \& Francis: 1089-1102. doi:10.1080/09537325.2016.1269160.

Huang, Ming Hui, and Roland T. Rust. 2018. "Artificial Intelligence in Service." Journal of Service Research 21 (2): 155-72. doi:10.1177/1094670517752459.

Huang, Zhenyu, Brian D. Janz, and Mark N. Frolick. 2008. "A Comprehensive Examination of Internet-EDI Adoption." Information Systems Management 25 (3): 273-86. doi:10.1080/10580530802151228.

Hwang, Bang Ning, Chi Yo Huang, and Chih Hsiung Wu. 2016. "A TOE Approach to Establish a Green Supply Chain Adoption Decision Model in the Semiconductor Industry." Sustainability (Switzerland) 8 (2). doi:10.3390/su8020168.

Iacovou, Charalambos L., Izak Benbasat, and Albert S. Dexter. 1995. "Electronic Data Interchange and Small Organizations: Adoption and Impact of Technology." MIS Quarterly: Management Information Systems 19 (4): 465-85. doi:10.2307/249629.

IBEF. 2019. "Auto Components." https://www.ibef.org/industry/autocomponents-india.aspx.

IFR. 2018. "Executive Summary World Robotics 2018 Industrial Robots." https://ifr.org/downloads/press2018/Executive_Summary_WR_2018_Industrial_Robots. pdf.

Ivanov, Stanislav, Craig Webster, and Katerina Berezina. 2018. "Adoption of Robots and Service Automation by Tourism and Hospitality Companies." Revista Turismo \& Desenvolvimento 1 (27/28): 1501-17.

Jasimuddin, Sajjad M., Nishikant Mishra, and Nasser A. Saif Almuraqab. 2017. "Modelling the Factors That Influence the Acceptance of Digital Technologies in E-Government Services in the UAE: A PLS-SEM Approach." Production Planning and Control 28 (16): 1307-17. doi:10.1080/09537287.2017.1375144.

Jia, Qiaong, Yue Guo, and Stuart Barnes. 2016. "Enterprise 2.0 Post-Adoption: Extending the Information System Continuance Model Based on the Technology-OrganizationEnvironment Framework." Computers in Human Behavior 67 (September): 95-105. doi:10.1016/j.chb.2016.10.022.

Kamble, Sachin, Angappa Gunasekaran, and Himanshu Arha. 2019. "Understanding the Blockchain Technology Adoption in Supply Chains-Indian Context." International Journal of Production Research 57 (7). Taylor \& Francis: 2009-33. doi:10.1080/00207543.2018.1518610.

Kaplan, Andreas, and Michael Haenlein. 2019. "Siri, Siri, in My Hand: Who's the Fairest in the Land? On the Interpretations, Illustrations, and Implications of Artificial Intelligence." Business Horizons 62 (1). "Kelley School of Business, Indiana University": 15-25. doi:10.1016/j.bushor.2018.08.004.

Kildal, Johan, Izaskun Fernández, Paul Stief, Jean-yves Dantan, Alain Etienne, and Ali Siadat. 2018. "Potential Users ' Key Concerns and Expectations for the Adoption of Cobots." In Procedia CIRP, 72:21-26. doi:10.1016/j.procir.2018.03.104.

Kopacek, P. 1999. "Intelligent Manufacturing: Present State and Future Trends." Journal of Intelligent and Robotic Systems: Theory and Applications 26 (3): 217-29. doi:10.1023/A:1008168605803.

Kumar, Karippur, Shalini Chandra, and Sushma Manava. 2016. "Factors Influencing Adoption 
of Agumentted Reality Technology for E-Commerce." Factors Influencing Adoption of Augmented Reality Technology for E-Commerce 342. http://aisel.aisnet.org/pacis2016/342.

Lai, Yuan, Huifen Sun, and Jifan Ren. 2018. "Article Information : Adoption in Logistics and Supply Chain Management: An Empirical." International Journal of Logistics Management. doi:10.1128/JB.00127-13.

Li, Bo hu, Bao cun Hou, Wen tao Yu, Xiao bing Lu, and Chun wei Yang. 2017. "Applications of Artificial Intelligence in Intelligent Manufacturing: A Review." Frontiers of Information Technology and Electronic Engineering 18 (1): 86-96. doi:10.1631/FITEE.1601885.

Lin, Chieh Yu, and Yi Hui Ho. 2009. "RFID Technology Adoption and Supply Chain Performance: An Empirical Study in China's Logistics Industry." Supply Chain Management: An International Journal $14 \quad$ (5): 369-78. doi:10.1108/13598540910980288.

Lin, Danping, C. K.M. Lee, Henry Lau, and Yang Yang. 2018. "Strategic Response to Industry 4.0: An Empirical Investigation on the Chinese Automotive Industry." Industrial Management and Data Systems 118 (3): 589-605. doi:10.1108/IMDS-09-2017-0403.

Lin, Hsiu Fen. 2014. "Understanding the Determinants of Electronic Supply Chain Management System Adoption: Using the Technology-Organization-Environment Framework." Technological Forecasting and Social Change 86. Elsevier Inc.: 80-92. doi:10.1016/j.techfore.2013.09.001.

Maduku, Daniel K., Mercy Mpinganjira, and Helen Duh. 2016. "Understanding Mobile Marketing Adoption Intention by South African SMEs: A Multi-Perspective Framework." International Journal of Information Management 36 (5). Elsevier Ltd: 711-23. doi:10.1016/j.ijinfomgt.2016.04.018.

Mani, Sunil. 2018. "Robot Apocalypse: Does It Matter for Indiaas Manufacturing Industry?" SSRN Electronic Journal. Tokyo. doi:10.2139/ssrn.3182255.

Mariani, Marcello M., Matteo Borghi, and Sergey Kazakov. 2019. "The Role of Language in the Online Evaluation of Hospitality Service Encounters: An Empirical Study." International Journal of Hospitality Management 78 (October 2018). Elsevier: 50-58. doi:10.1016/j.ijhm.2018.11.012.

Masood, Tariq, and Johannes Egger. 2019. "Augmented Reality in Support of Industry 4.0Implementation Challenges and Success Factors." Robotics and Computer-Integrated Manufacturing 58: 181-95. doi:10.1016/j.rcim.2019.02.003.

Mathews, Sam. 2017. "India Ready to Accelerate Industrial Robotics Adoption." Systemantics.Com. http://www.systemantics.com/2017/04/24/india-ready-to-accelerateindustrial-robotics-adoption/.

Menifestias. 2020. "Robotics In India." Manifestias.Com. https://www.manifestias.com/2020/02/28/robotics-in-india/.

Mittal, Sameer, Muztoba Ahmad Khan, Jayant Kishor Purohit, Karan Menon, David Romero, and Thorsten Wuest. 2019. "A Smart Manufacturing Adoption Framework for SMEs." International Journal of Production Research 0 (0). Taylor \& Francis: 1-19. doi:10.1080/00207543.2019.1661540.

Müller-abdelrazeq, Sarah L, Kathrin Schönefeld, Max Haberstroh, and Frank Hees. 2019. "Interacting with Collaborative Robots - A Study on Attitudes and Acceptance in Industrial Contexts." In Social Robots: Technological, Societal and Ethical Aspects OfHuman-Robot Interaction, Human-Computer Interaction Series, 101-17. Springer International Publishing. doi:10.1007/978-3-030-17107-0.

Nunnally, J.C. 1978. Psychometric Theory. Edited by 2. New York, NY.: McGraw-Hill. OEMupdate. 2018. "Top Robotic Applications in Automotive Industry." OEMupdate.Com. 
http://www.oemupdate.com/technology/top-robotic-applications-in-automotiveindustry/.

Oliveira, Tiago, and Maria F. Martins. 2010. "Understanding E-Business Adoption across Industries in European Countries." Industrial Management and Data Systems 110 (9): 1337-54. doi:10.1108/02635571011087428.

Oliveira, Tiago, Ricardo Martins, Saonee Sarker, Manoj Thomas, and Aleš Popovič. 2019. "Understanding SaaS Adoption: The Moderating Impact of the Environment Context." International Journal of Information Management 49: 1-12. doi:10.1016/j.ijinfomgt.2019.02.009.

Oliveira, Tiago, Manoj Thomas, and Mariana Espadanal. 2014. "Assessing the Determinants of Cloud Computing Adoption: An Analysis of the Manufacturing and Services Sectors." Information and Management 51 (5): 497-510. doi:10.1016/j.im.2014.03.006.

Osakwe, Christian Nedu, Miloslava Chovancová, and Monica Agu. 2016. "Can MicroEnterprises Leverage on the Adoption of Corporate Websites to Bolster Their Brand Visibility? Examining Salient Adoption Issues in Nigeria." Information Development 32 (4): 904-19. doi:10.1177/0266666915573551.

P.G.W. Keen. 1991. "Shaping the Future." Harvard Business School Press, . Boston, MA.

Pan, Yunhe. 2016. "Heading toward Artificial Intelligence 2.0." Engineering 2 (4). Elsevier LTD on behalf of Chinese Academy of Engineering and Higher Education Press Limited Company: 409-13. doi:10.1016/J.ENG.2016.04.018.

Park, Eunil, and Sang Jib Kwon. 2016. "The Adoption of Teaching Assistant Robots: A Technology Acceptance Model Approach.” Program 50 (4): 354-66. doi:10.1108/PROG02-2016-0017.

Paryanto, Matthias Brossog, Martin Bornschlegl, and Jörg Franke. 2015. "Reducing the Energy Consumption of Industrial Robots in Manufacturing Systems." International Journal of Advanced Manufacturing Technology 78 (5-8): 1315-28. doi:10.1007/s00170-014-6737$\mathrm{Z}$.

Penrose, E.T. 1958. The Theory of the Growth of the Firm. New York: Wiley.

Peteraf, Margaret. 1993. "The Cornerstones of Competitive Advantage: A Resource-Based View Margaret." Strategic Management Journal 14 (3): 179-91. doi:10.4324/9780203847589.

Pillai, Rajasshrie, and Brijesh Sivathanu. 2020. "Adoption of Artificial Intelligence (AI) for Talent Acquisition in IT/ITeS Organizations." Benchmarking: An International Journal. doi:10.1108/BIJ-04-2020-0186.

Pillai, Rajasshrie, Brijesh Sivathanu, and Yogesh K. Dwivedi. 2020. "Shopping Intention at AI-Powered Automated Retail Stores (AIPARS)." Journal of Retailing and Consumer Services 57: 102207. doi:10.1016/j.jretconser.2020.102207.

Podsakoff, Philip M., Scott B. MacKenzie, Jeong Yeon Lee, and Nathan P. Podsakoff. 2003. "Common Method Biases in Behavioral Research: A Critical Review of the Literature and Recommended Remedies." Journal of Applied Psychology 88 (5): 879-903. doi:10.1037/0021-9010.88.5.879.

Podsakoff, Philip M., and Dennis W. Organ. 1986. "Self-Reports in Organizational Research: Problems and Prospects." Journal of Management 12 (4): 531-44. doi:10.1177/014920638601200408.

Puklavec, Borut, Tiago Oliveira, and Aleš Popovič. 2018. "Understanding the Determinants of Business Intelligence System Adoption Stages an Empirical Study of SMEs." Industrial Management and Data Systems 118 (1): 236-61. doi:10.1108/IMDS-05-2017-0170.

PWC. 2018. "Adopting a New Generation of Industrial Robots.” $P w C$, no. June: 17.

-. 2019. "Indian Automotive Sector: Creating Future -Ready Organizations." https://www.pwc.in/assets/pdfs/industries/automotive/indian-automotive-sector.pdf. 
Queiroz, Maciel M., and Samuel Fosso Wamba. 2019. "Blockchain Adoption Challenges in Supply Chain: An Empirical Investigation of the Main Drivers in India and the USA." International Journal of Information Management 46: 70-82. doi:10.1016/j.ijinfomgt.2018.11.021.

Ramanathan, Ramakrishnan, Elly Philpott, Yanqing Duan, and Guangming Cao. 2017. "Adoption of Business Analytics and Impact on Performance: A Qualitative Study in Retail." Production Planning and Control 28 (11-12): 985-98. doi:10.1080/09537287.2017.1336800.

Rampasso, Izabela S., Rosley Anholon, Dirceu da Silva, Robert E.C. Ordóñez, and Osvaldo L.G. Quelhas. 2019. "Maturity Analysis of Manufacturing Cells." Production Planning and Control 30 (15): 1250-64. doi:10.1080/09537287.2019.1612108.

Reyes, Pedro M., Suhong Li, and John K. Visich. 2016. "Determinants of RFID Adoption Stage and Perceived Benefits." European Journal of Operational Research 254 (3): 80112. doi:10.1016/j.ejor.2016.03.051.

Ringle, C.M., Wende, S. and Will, A. 2005. "Smart PLS 2.0.” https://www.smartpls.com/.

Roger, E. 1995. Diffusion of Innovations. 4th ed. New York: The Free Press.

Rumelt, R. 1984. "Towards a Strategic Theory of the Firm." In R. Lamb (Ed.), Competitive Strategic Management, 556-570. Englewood Cliffs, NJ: Prentice-Hall.

Russell, Stuart, and Peter Norvig. 2016. Artificial Intelligence: A Modern Approach. Malaysia: Perason Education limited. doi:10.1108/JBIM-06-2016-0122.

Sackey, Samuel Mensah, and Andre Bester. 2016. "Industrial Engineering Curriculum in Industry 4.0 in a South African Context." South African Journal of Industrial Engineering 27 (4): 101-14. doi:10.7166/27-4-1579.

Sangani, Priyanka. 2019. "Automation Is Sweeping across India's Manufacturing Space." Economic

Times.

//economictimes.indiatimes.com/articleshow/69262579.cms?utm_source=contentofinter est\&utm_medium=text\&utm_campaign=cppst.

Sangomla, Akshit. 2019. "Robots Are Here, Almost." Downtoearth.Org.In. https://www.downtoearth.org.in/news/science-technology/robots-are-here-almost63433.

Schmidt, Rainer, Michael Mohring, Ralf-Christian Harting, Christopher Reichstein, Pascal Neumaier, and Philip Jozinovic. 2015. "Industry 4.0 - Potentials for Creating Smart Product: Empirical Reserach Results." In Business Information Systems :18th International Conference, BIS 2015 Poznań, Poland, Proceedings. Vol. 208. doi:10.1007/978-3-319-19027-3.

Schuetz, Sebastian, and Viswanath Venkatesh. 2019. "Blockchain, Adoption, and Financial Inclusion in India: Research Opportunities." International Journal of Information Management, 1-8. doi:10.1016/j.ijinfomgt.2019.04.009.

Shaltoni, Abdel. 2016. "From Websites to Social Media: Exploring the Adoption of Internet Marketing in Emerging Industrial Markets." Journal of Business \& Industrial Marketing 32 (7): 1009-10019. doi:10.1108/JBIM-06-2016-0122.

Simoes, Ana C, Antonio L Soares, and Ana C Barros. 2019. "Drivers Impacting Cobots Adoption in Manufacturing Context: A Qualitative Study." In Advances in Manufacturing II, 1:203-12. Springer Nature Switzerland AG. doi:10.1007/978-3-03018715-6.

Sivathanu, Brijesh. 2019. "Adoption of Industrial IoT (IIoT) in Auto-Component Manufacturing SMEs in India." Information Resources Management Journal 32 (2): 5257.

Soffar, Heba. 2019. "Industrial Robot (Auto Industry) Uses, Advantages and Disadvantages." Online Sciences. https://www.online-sciences.com/robotics/industrial-robot-auto- 
industry-uses-advantages-and-disadvantages/.

Steven, Marks. 2019. "Pros and Cons of Using Industrial Robots in Your Manufacturing Operation." Wilfli.Com. https://www.wipfli.com/insights/blogs/manufacturingtomorrow-blog/pros-and-cons-of-industrial-robots-in-manufacturing.

Sun, Shiwei, Casey G. Cegielski, Lin Jia, and Dianne J. Hall. 2018. "Understanding the Factors Affecting the Organizational Adoption of Big Data." Journal of Computer Information Systems 58 (3). Taylor \& Francis: 193-203. doi:10.1080/08874417.2016.1222891.

Tapiero, Charles S. 1990. "Technology and the Manufacturing Process." Production Planning and Control 1 (2): 85-91. doi:10.1080/09537289008919301.

Teece, David J., Gary Pisano, and Amy Shuen. 1997. "Dynamic Capabilities and Strategic Management." Strategic Management Journal 18 (7): 509-33. doi:10.1142/9789812834478_0002.

Teulieres, Marc, Jonathan Tilley, Lea Bolz, Peter Leuwing-Dehm, and Susanne Wagner. 2019. "Industrial Robotics - Insights into the Sector's Grwoth Dynamics." Mckinsey \& Company. $\quad$ https://www.mckinsey.com/ /media/McKinsey/Industries/Advanced Electronics/Our Insights/Growth dynamics in industrial robotics/Industrial-roboticsInsights-into-the-sectors-future-growth-dynamics.ashx.

Times, Economic. 2019. "Tech's Still a Strange Word for Manufacturers Here." Economictimes.Com. https://economictimes.indiatimes.com/tech/hardware/techs-still-astrange-word-for-manufacturers-here/articleshow/71472489.cms.

Troshani, Indrit, Cate Jerram, and Michael Gerrard. 2010. "Exploring the Organizational Adoption of Human Resources Information Systems (HRIS) in the Australian Public Sector." ACIS 2010 Proceedings - 21st Australasian Conference on Information Systems.

Tsou, Hung Tai, and Sheila Hsuan Yu Hsu. 2015. "Performance Effects of TechnologyOrganization-Environment Openness, Service Co-Production, and Digital-Resource Readiness: The Case of the IT Industry." International Journal of Information Management 35 (1): 1-14. doi:10.1016/j.ijinfomgt.2014.09.001.

Turja, Tuuli, and Atte Oksanen. 2019. "Robot Acceptance at Work: A Multilevel Analysis Based on 27 EU Countries." International Journal of Social Robotics, no. 0123456789. Springer Netherlands. doi:10.1007/s12369-019-00526-x.

Venkatesh, Viswanath, and Fred D Davis. 2000. "A Theoretical Extension of the Technology Acceptance Model: Four Longitudinal Field Studies." Management Science 46 (2): 186204. doi:10.1287/mnsc.46.2.186.11926.

Wang, Yi Shun, Ching Hsuan Yeh, and Yi Wen Liao. 2013. "What Drives Purchase Intention in the Context of Online Content Services? The Moderating Role of Ethical Self-Efficacy for Online Piracy." International Journal of Information Management 33 (1): 199-208. doi:10.1016/j.ijinfomgt.2012.09.004.

Wang, Yu Min, Yi Shun Wang, and Yong Fu Yang. 2010. "Understanding the Determinants of RFID Adoption in the Manufacturing Industry." Technological Forecasting and Social Change 77 (5): 803-15. doi:10.1016/j.techfore.2010.03.006.

Wang, Yu Yin, Yi Shun Wang, and Tung Ching Lin. 2018. "Developing and Validating a Technology Upgrade Model." International Journal of Information Management 38 (1): 7-26. doi:10.1016/j.ijinfomgt.2017.07.003.

Wei, Jie, Paul Benjamin Lowry, and Stefan Seedorf. 2015. "The Assimilation of RFID Technology by Chinese Companies: A Technology Diffusion Perspective." Information and Management 52 (6): 628-42. doi:10.1016/j.im.2015.05.001.

Wernerfelt. 1984. “A Resource Based View of the Firm." Strategic Management Journal 5 (171): 180.

Yeh, Ching Chiang, and Yi Fan Chen. 2018. "Critical Success Factors for Adoption of 3D Printing." Technological Forecasting and Social Change 33 (6): 209-16. 
doi:10.1016/j.techfore.2018.02.003.

Zhu, Kevin, and Kenneth L. Kraemer. 2005. "Post-Adoption Variations in Usage and Value of e-Business by Organizations: Cross-Country Evidence from the Retail Industry." Information Systems Research 16 (1): 61-84. doi:10.1287/isre.1050.0045. 